\title{
Spheres, Sefirot, and the Imaginal Astronomical Discourse of Classical Kabbalah*
}

\author{
J. H. Chajes
}

University of Haifa; chajes@research.haifa.ac.il

\begin{abstract}
The medieval expression of Jewish esotericism known as Kabbalah is distinguished by its imaging of the divine as ten hypostatic sefirot that structure the Godhead and generate the cosmos. Since Gershom Scholem, the preeminent twentieth-century scholar of Kabbalah, declared the term sefirah (sg.) as deriving from "sapphire"pointedly rejecting its connection to the Greek $\sigma \varphi \alpha \tilde{i} \rho \alpha$-scholars have paid scant attention to the profound indebtedness of the visual and verbal lexicon of the kabbalists to the Greco-Arabic scientific tradition. The present paper seeks to redress this neglect through an examination of the appropriation of the diagrammaticiconographical and rhetorical languages of astronomy and natural philosophy in medieval and early modern kabbalistic discourse. This study will place particular emphasis on the adoption-adaptation and ontologization of the dominant schemata of these most prestigious fields of medieval science by classical kabbalists, what it reveals about their self-understanding, and how it contributed to the perception of Kabbalah as a "divine science" well into the early modern period.
\end{abstract}

\section{Keywords}

Kabbalah, 'ilanot, Tree of Life, diagrams, visualization of knowledge, astronomy

* This research was supported by the Israel Science Foundation (Grant 1568/18). 


\section{Kabbalistic Diagrams, Scientific Diagrams}

"One who begins the study of this science [חכמה] must know that he must first learn all of the drawings [הציורים], and how all the worlds descend [משתלשלים] one after another. And all of them must be drawn [מצוירים] before him so that he comprehend and understand these matters." So begins the final chapter of "Introductions and Keys Appropriate for All Who Would Enter the Science of the Kabbalah to Know" [הקדמות ומפתחות שראוי לכל הנכנס לחכמת הקבלה לדעת אותן], an introduction to the Kabbalah, apparently of early sixteenth-century Italian provenance. ${ }^{2}$ The complete introductory course is extant in one manuscript and hasn't a single diagram. Instead, as a kind of final project, the student is instructed to draft a large and complex drawing to represent the knowledge acquired in the preceding chapters on the basis of the very precise and technical verbal instructions to which the final chapter is entirely devoted. To be a student of the Kabbalah is to visualize its knowledge as a graphic no less than a mental image. ${ }^{3}$

The importance of the diagrammatic image to kabbalists stands in sharp contrast to their relative invisibility in scholarship. Long neglected by scholars of Kabbalah, diagrams have figured as eye-candy illustrations alongside unrelated discussions and as raw material for book-jacket designers. Even when recognized as intrinsic features of kabbalistic works, they have been dismissed as "concealing much more than they reveal," in the words of Gershom Scholem. ${ }^{4}$ Scientific diagrams were similarly neglected by generations of historians of science, no doubt as a result of prejudices that strongly favored word over image; this neglect, however,

${ }^{1}$ Jewish Theological Seminary MS 1990, 106a. The final chapter (without the rest of the introduction) is extant in Oxford - Bodleian Library MS Christ Church 188 and JTS MS 2030. I am currently preparing an edition of this work with Dr. Eliezer Baumgarten.

${ }^{2}$ Kabbalah here refers to the Jewish esoteric lore that emerged in Provence and Northern Spain in the twelfth and thirteenth centuries.

${ }^{3}$ Were it not for the fact that this passage is followed by detailed drafting instructions for a highly complex diagram, the key term/root צ could have been rendered here "visualized conceptualization." See below. On the term in the Italian Kabbalah of the period, see Fabrizio Lelli, "Osservazioni sull'uso del termine siyyur in alcuni trattati cabbalistici dell'Italia rinascimentale," Materia giudaica 15/16 (2010) 331-38.

${ }^{4}$ Gershom Scholem, "Rabbi David Ben Judah Hehasid, Grandson of the Ramban," Qiryat Sefer 4 (1927) 302-27, at 310 (Hebrew). For a discussion of the fortunes of the visual element of Kabbalah in scholarship, see Giulio Busi, "Beyond the Burden of Idealism: For a New Appreciation of the Visual Lore in the Kabbalah," in Kabbalah and Modernity: Interpretations, Transformations, Adaptations (ed. Boaz Huss, Marco Pasi, and Kocku von Stuckrad; Leiden: Brill, 2010) 29-46. For the same author's pioneering survey of "visual Kabbalah," see idem, Qabbalah Visiva (Einaudi: Torino, 2005). Another vanguard study, this one focusing on a small corpus, albeit broadly theorized, is Marla Segol, Word and Image in Medieval Kabbalah: The Texts, Commentaries, and Diagrams of the Sefer Yetsirah (The New Middle Ages; New York: Palgrave Macmillan, 2012). See also the general remarks in Daniel Abrams, "Kabbalistic Paratext," Kabbalah: Journal for the Study of Jewish Mystical Texts 26 (2012) 7-24; idem, Kabbalistic Manuscripts and Textual Theory: Methodologies of Textual Scholarship and Editorial Practice in the Study of Jewish Mysticism (2nd ed.; Sources and Studies in the Literature of Jewish Mysticism 36; Jerusalem: Magnes; Los Angeles: Cherub, 2013) 618-26. 
was replaced with steadily growing interest beginning some thirty years ago. ${ }^{5}$ With fashionable tardiness, the visual materials of the Kabbalah are now being interrogated for their potential contribution to a more embedded history that goes beyond theosophical concepts to treat epistemic, hermeneutic, performative, and pedagogical dimensions of kabbalistic culture. Much of this recent work exposes the shared discursive and schematic constructs of early modern science and Kabbalah. ${ }^{6}$ In the present paper, I turn my attention to medieval sources to examine the appropriation of the visual and rhetorical languages of astronomy and natural philosophy by the classical kabbalists and what it reveals about how they conceptualized their endeavor.

The fact that basic research on kabbalistic diagrams - by which I mean systematic collection, classification, and contextualization — began just a few years ago rather than in the first century of modern scholarship belies their significance in the eyes of the kabbalists themselves. As most of what follows will focus on materials produced by Jews, I here invoke the learned Christian Hebraist and scholar of the Kabbalah, Guillaume Postel (1510-1581). Writing in mid-sixteenth-century Venice, Postel listed the main genres of Hebraica for his interested coreligionists. ${ }^{7}$ Alongside Bible, Talmud, and Midrash, we find " 'Ilanoth" - Trees. Postel was well aware of the parchment "iconotexts" of kabbalistic cosmology and regarded them as a genre in their own right. It is probably fair to say that the heyday of 'ilanot occurred in sixteenth-century Italy, including grand luxury parchments crafted in

\footnotetext{
${ }^{5}$ See, e.g., Martin J. S. Rudwick, "The Emergence of a Visual Language for Geological Science 1760-1840," History of Science 14 (1976) 149-95; John Emery Murdoch, Antiquity and the Middle Ages (Album of Science; New York: Scribner, 1984). Important recent studies include Christoph Lüthy and Alexis Smets, "Words, Lines, Diagrams, Images: Towards a History of Scientific Imagery," Early Science and Medicine 14 (2009) 398-439; Wolfgang Lefèvre, Jürgen Renn, and Urs Schoepflin, The Power of Images in Early Modern Science (Basel: Birkhäuser Verlag, 2003).

${ }^{6}$ For the early modern period, see J. H. Chajes, "Kabbalah and the Diagrammatic Phase of the Scientific Revolution," in Jewish Culture in Early Modern Europe: Essays in Honor of David B. Ruderman (ed. Richard I. Cohen et al.; Cincinnati, OH: Hebrew Union College Press, 2014) 109-23. Although my methodology in the present paper may aptly be described as discursive analysis, the approach throughout will be philological. In lieu of providing a theorized justification of this methodology, the reader is referred to Kocku von Stuckrad, "Discursive Study of Religion: From States of the Mind to Communication and Action," Method and Theory in the Study of Religion 15 (2003) 255-71.

${ }^{7}$ See Robert Wilkinson, Orientalism, Aramaic, and Kabbalah in the Catholic Reformation: The First Printing of the Syriac New Testament (Leiden: Brill, 2007) 119 n. 82. Judith Weiss was kind enough to bring this usage of Postel's to my attention. See Judith Weiss, A Kabbalistic Christian Messiah in the Renaissance: Guillaume Postel and the Book of Zohar (Jerusalem: Hakibbutz Hameuchad-Sifriat Poalim, 2017) 92 n. 274 and 100 n. 324 (Hebrew).

${ }^{8}$ The term seems apt here in Alain Montandon's sense: "works of art in which writing and the plastic element present themselves in an inseparable totality." See Iconotextes (ed. Alain Montandon; Paris: Ophrys, 1990) 268. I would only emphasize that kabbalistic diagrams are, generally speaking, "images that are not art," about which see James Elkins, "Art History and Images That Are Not Art," Art Bulletin 77 (1995) 553-71.
} 
fine Renaissance style. Exquisite copies of one such "magnificent parchment" may be found today in libraries and private collections around the world. ${ }^{9}$

The rich variety of divinity maps reflects the particular epistemological, theological, and cultural orientations of their producers. ${ }^{10}$ Variation notwithstanding, however, most kabbalistic divinity maps diagrammed the sefirot. Kabbalah refers to the diverse expressions of Jewish medieval esotericism that imaged God as ten hypostatic powers (the sefirot) susceptible to the influence-both positive and negative - of human action. These emanated ontologized divine qualities also determined the structure of the cosmos, top to bottom. Whether understood as facets of divine essence or as modes of divine action, the sefirot were presumed to be meaningfully arrayed and dynamically creative: their emergence, order, and interconnections provided the key not only to the Book of Scripture but also to the Book of Nature. ${ }^{11}$

How did this work theologically? Kabbalists distinguished between two facets of the Godhead. The "true" God was conceptualized as infinite and even called "Nothing" (אין), and may be compared to - and was undoubtedly influenced byMaimonidean apophatism. ${ }^{12}$ Naturally this dimension is concealed and beyond apprehension, and certainly not the biblical character called "God." The famous opening of the Zohar on Genesis thus reads "God" as the object of the first verse, and the Infinite as its hidden subject (Zohar I 15a). The revealed dimension of the Godhead emerges - or, more precisely, emanates — as the ten sefirot. The meaning of the term sefirot is anything but obvious. Its Hebrew root for a range of words including book (ספר), story (סיפור), number (ספרה ספרר), and even sapphire (ספיר). As we shall see, the Greek $\sigma \varphi \alpha \tilde{i} \rho \alpha$ is ostensibly a false, if not irrelevant, cognate.

${ }^{9}$ I refer to the manuscript family that includes Oxford - Bodleian Library MS Hunt. Add. D, British Library MS Or. 6465, Vatican Library MS ebr. 598, and Hebrew Union College Scroll XIV-7, among others. The British Library witness - a mid-sixteenth-century copy accomplished in Modena by the itinerant Polish rabbi, David Darshan, is the only one currently viewable online: https:// www.bl.uk/collection-items/olam-sefirot-or-6465. See below, note 66. With Volkswagen Foundation funding, and in collaboration with the digital humanities lab at the University of Göttingen, the University of Haifa "Ilanot Project" team is currently preparing a digital edition of "The Magnificent Parchment." For a survey of the 'ilanot of this provenance, see J. H. Chajes, "Kabbalistic Trees (Ilanot) in Italy: Visualizing the Hierarchy of the Heavens," in The Renaissance Speaks Hebrew (ed. Giulio Busi and Silvana Greco; Milan: Silvana Editoriale, 2019) 170-83.

${ }^{10}$ On the necessity to contextualize diagrams historically, see Lüthy and Smets, "Words, Lines, Diagrams, Images," 398-439. The absence of any universal terminological taxonomy makes it especially important to be acutely aware of the particular language used for what I here call the diagram. I have thus endeavoured to present the original terms wherever possible in what follows.

${ }^{11}$ For a discussion of these terms in the early modern period, see Peter Harrison, "The "Book of Nature' and Early Modern Science," in The Book of Nature in Early Modern and Modern History (ed. Klaas van Berkel and Arjo Vanderjagt; Leuven: Peeters, 2006) 1-26.

${ }^{12}$ For a comparative treatment, see Michael A. Sells, Mystical Languages of Unsaying (Chicago: University of Chicago Press, 1994). 
That there were ten sefirot was axiomatic because of the emphatic pronouncement of Sefer yeșirah (Book of Formation) on the subject: "Ten sefirot without substance (בלימה), ${ }^{13}$ ten and not nine, ten and not eleven." ${ }^{14}$ A laconic cosmological work of late antique provenance resembling nothing else in Jewish literature, and canonical by the early tenth century, Sefer yeșirah proclaimed in an apodictic tone that God carved out the cosmos with thirty-two wondrous paths of wisdom, these being the ten sefirot and the twenty-two letters of the Hebrew alphabet. ${ }^{15}$ The latter were in turn divided into three groups of three, seven, and twelve. The early kabbalists took Sefer yeșirah as a biblical-style base text, writing commentaries and citing it endlessly. Kabbalists found it a congenial matrix upon which to project their own speculative content.

The ascent of Sefer yeșirah was certainly due to a perception of it as a scientific work in a cultural context that valorized the sciences - the Abbasid Caliphate of the ninth century - that Jews could call their own. The earliest commentary on the work, penned in the first half of the tenth century by Sa'adiah Gaon, effectively conferred upon it canonical status and treated it as a Jewish work of science. For some two hundred years thereafter, this perception would be shared by all commentators on the work. ${ }^{16}$ Its subsequent appropriation by kabbalists might best be seen as an outgrowth of this perception rather than as a dramatic about-face in its reception. ${ }^{17}$

The ten sefirot of Sefer yeșirah share little more than name and number with those developed in medieval theosophical Kabbalah, though in both cases they

13 Probably an allusion to Job 26:7— "hangs the earth over nothing (בלי מה)." See A. Peter Hayman, Sefer Yeșira: Edition, Translation and Text-Critical Commentary (Tübingen: Mohr Siebeck, 2004) 66. R. Isaac of Acre modified the term slightly to introduce a concentric-circle diagram of the sefirot in his influential thirteenth-century kabbalistic work Me'irat 'eynayim (Light of the Eyes): "And this is the form of the array (צורת העמדתן) of the ten sefirot without essence/substance (בלי) מהות)." See Amos Goldreich, "Sefer me'irat 'eynayim le-r. Yiṣhak de-min Akko," (PhD diss., The Hebrew University of Jerusalem, 1981) 118 (Hebrew). The reading found in the standard (but not scientific) edition reads "of the divine" (האלהית) rather than "of the array" (העמדתן). See R. Yișhak de-min Akko, Sefer me'irat 'eynayim (Jerusalem, 1975) 152a (Hebrew).

${ }^{14}$ Hayman, Sefer Yeșira, 69-70.

${ }^{15}$ For a recent discussion and bibliography, see Tzahi Weiss, Sefer Yeșirah and Its Contexts: Other Jewish Voices (Philadelphia: University of Pennsylvania Press, 2018).

${ }^{16}$ Raphael Jospe, "Early Philosophical Commentaries on the Sefer Yezirah: Some Comments," Revue des études juives 149 (1990) 369-415; Y. Tzvi Langermann, "On the Beginnings of Hebrew Scientific Literature and on Studying History Through maqbilot (Parallels)," Aleph 2 (2002) 169-89. See also Langerman's unpublished essay at https:/www.academia.edu/s/89185cbbb7/מריצ-ירה ממדע-לקבלה-ובחזרה-גירסת-אינטרנט.

17 See Mark Brian Sendor, "The Emergence of Provencal Kabbalah: Rabbi Isaac the Blind's Commentary on Sefer Yezirah" (PhD diss., Harvard University, 1994). See now Avishai BarAsher, "Illusion versus Reality in the Study of Early Kabbalah: The Commentary on Sefer Yeșirah Attributed to Isaac the Blind and Its History in Kabbalah and Scholarship," Tarbits 86.2-3 (2019): 269-384 (Hebrew). 


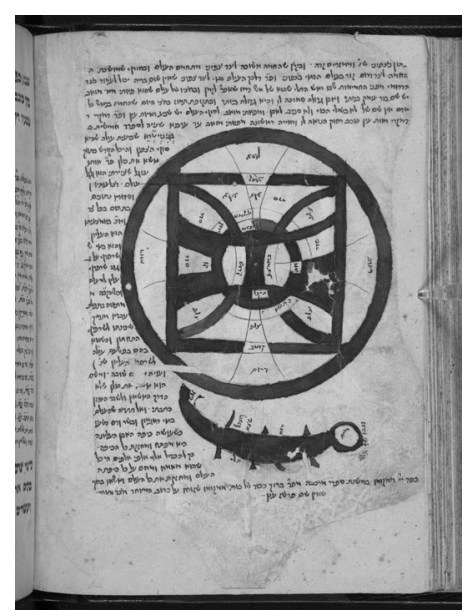

Figure 1: (C) British Library Board (British Foundation Catalogue of Digitised Hebrew Manuscripts. Library Add. MS 27089 81v); Polonsky

are understood as the fundamental elements of creation. ${ }^{18}$ In the former, we find them identified as the six vectors of three-dimensional space, the two vectors (or endpoints) of time, and the two vectors of value (good and evil). ${ }^{19}$ In the latter, the sefirot are the nodes of a emanatory network, ten qualities (perhaps not uncoincidentally paralleling Aristotle's ten categories) of endless combinatory creative potential that articulate a denary Godhead. These sefirot, the contemplation of which constitutes the very heart of medieval theosophical Kabbalah, are named with attributes borrowed from 1 Chronicles 29:11: "Thine, O Lord, is the greatness, and the power, and the glory, and the victory, and the majesty."

It may be observed that the ten sefirot of Sefer yesirah - space, time, and value - could be, and in fact were, diagrammed with relative ease with the common schemata of medieval natural philosophy. ${ }^{20}$ A schema going back to Isidore of Seville's revolutionary seventh-century treatise on the natural world-De natura rerum, known in the Middle Ages as "The Book of Wheels" (Liber rotarum)-seems closely related to the cosmological world of Sefer yeșirah and indeed centers around the inscription "Mundus-Annus-Homo," which quite literally appears in Sefer yeșirah as "world year person" (עולם שנה נפש). ${ }^{21}$ Isidore's diagram may be found in the early kabbalistic commentary to Sefer yesirah ascribed to R. Sa'adiah Gaon, and its long afterlife includes an appearance in a fascinating illustrated scientific primer of seventeenth-century Ashkenazic provenance entitled Surat sidrey 'olam (The Form of the Orders of the World) [Figure 1].22

${ }^{18}$ For a recent attempt to establish the meaning of the term in Sefer yeșirah, see Giulio Busi, “"Engraved, Hewed, Sealed': Sefirot and Divine Writing in 'Sefer Yetzirah,'” Jerusalem Studies in Jewish Thought 21 (2007) 1-11.

${ }^{19}$ Hayman, Sefer Yeșira, 76, §7. Even within Sefer yeșirah, these identifications are fluid, and we find an alternative already in §16. Instead of beginning, end, good, and evil, are "the Spirit of the Living God; and air, water, fire." Hayman, Sefer Yeșira, 91.

${ }^{20}$ See Barbara Obrist, "Wind Diagrams and Medieval Cosmology," Speculum 72 (1997) 33-84.

${ }^{21}$ This diagram is the cover image of Isidore of Seville: On the Nature of Things (ed. Calvin B. Kendall and Faith Wallis; Liverpool: Liverpool University Press, 2016). Obrist discusses the diagram in Munich, Bayerische Staatsbibliothek, clm 16128, f. 16r, in Barbara Obrist, "The Idea of a Spherical Universe and Its Visualization in the Earlier Middle Ages," in The Visualization of Knowledge in the Middle Ages and the Early Modern Period (ed. Marcia Kupfer, Adam Cohen, and J. H. Chajes; Studies in the Visual Cultures of the Middle Ages 16; Turnhout: Brepols, 2020) 229-258.

${ }^{22}$ For kabbalistic appropriations, see BSB Cod.hebr. 40 62r, British Library Add. 27089 81v, National Library of Israel Ms. Yah. Heb. 75v. Both the diagrammatic and textual connections require additional research. 
The ten sefirot of the theosophical Kabbalah are, by contrast, abstractions. None of them bears intrinsic markers of location in space, whether in two or three dimensions, nor even self-evident relationality to one another. Nevertheless, the earliest extant kabbalistic manuscripts, copied from Spanish sources in Rome in the 1280 s, contain sefirotic diagrams, epistemic images "crafted expressly to accompany or even replace verbally transmitted explanations." ${ }^{23}$ Such images must be understood in their literary and cultural contexts rather than through any timeless taxonomy. The context of the literary emergence of the Kabbalah was twelfth-century Provence. ${ }^{24}$ Kabbalah, no less than philosophy, was symptomatic of the profound local Jewish engagement in the mediation of Greco-Arabic learning to Christian Europe. ${ }^{25}$ In this context, kabbalists and philosophers shared the estrangement from the mentalité of classical rabbinic thought that generated profound transvaluations of Jewish tradition. ${ }^{26}$ The occasional antagonism and polemic, sometimes fierce, between those who identified with one camp or the other should be understood as bespeaking proximity/similarity rather than distance/difference. ${ }^{27}$ As Hava Tirosh-Samuelson has shown, early Kabbalah may

${ }^{23}$ See Christoph Lüthy, "Not What, But Why and How," in What is an Image? (ed. James Elkins and Maja Naef; University Park: Pennsylvania State University Press, 2011) 182-85, at 183 . The early manuscripts are surveyed in Moshe Idel, The Kabbalist R. Menachem Recanati (Jerusalem: Schocken Press, 1998) 33-54 (Hebrew). Their diagrammatic content has been described by Busi, Qabbalah Visiva, 125-36. These materials are at the heart of Segol's Word and Image in Medieval Kabbalah.

${ }^{24}$ As no twelfth-century kabbalistic manuscripts are extant, we cannot determine what, if any, their diagrammatic content might have been. At issue, however, is the broader consideration of the kabbalistic appropriation of central scientific figures - verbal and visual - that I argue is consistent with the emergence of the Kabbalah in twelfth-century Provence. Although kabbalistic schools adopted a variety of postures vis-à-vis philosophy per se, innumerable studies have demonstrated the profound internalization of philosophical elements in even the most vocally anti-philosophical. Undoubtedly, local intellectual climates played a part in shaping the character of particular schools, resulting, among other things, in qualitative and quantitative differences in their diagrammatic efforts. Italy, as the reader may have already noticed en passant, stands out as a particularly rich locale for the production of kabbalistic diagrams from the thirteenth to the eighteenth centuries. Although not specifically dealing with this issue, see more generally Moshe Idel, Kabbalah in Italy, 1280-1510: A Survey (New Haven: Yale University Press, 2011). Returning to the so-called twelfth-century Renaissance, see Jews and Christians in Twelfth-Century Europe (ed. Michael Alan Signer and John H. Van Engen; Notre Dame: University of Notre Dame Press, 2000). For a review of the historiography treating this term and critiques of it, see Leidulf Melve, "The Revolt of the Medievalists': Directions in Recent Research on the Twelfth-Century Renaissance," Journal of Medieval History 32 (2006) 231-52. See also the pertinent study of Haviva Pedaya, "Siyyur and Temunah in the Kabbalistic Exegesis of Nachmanides," Mahanaim 6 (1993) 114-23 (Hebrew).

${ }^{25}$ For a consideration of the Provençal context in which the Kabbalah emerged, see Ram BenShalom, The Jews of Provence and Languedoc (Raanana: The Open University of Israel, 2017) 565-631 (Hebrew). See also the insightful remarks of Harvey J. Hames, The Art of Conversion: Christianity and Kabbalah in the Thirteenth Century (Leiden: Brill, 2000) 24-26.

${ }^{26}$ Moshe Halbertal grouped philosophers and kabbalists together in this period under the rubric of esotericism. See Moshe Halbertal, Concealment and Revelation: Esotericism in Jewish Thought and Its Philosophical Implications (Princeton: Princeton University Press, 2007).

${ }^{27}$ For an important, albeit underappreciated, contribution to the appreciation of the philosophical background of early Kabbalah, see Marc B. Sendor, “The Emergence of Provençal Kabbalah: Rabbi 
be understood as an expression of Platonic rather than Aristotelian science, the latter being associated with most medieval Jewish philosophers. Kabbalists held the Platonic view that

scientific knowledge pertains not to the natural world known through the senses but to the intelligible forms, the eternal, timeless, changeless realities that are arranged in a hierarchical order. . . Properly speaking, only knowledge of the intelligible forms constitutes "science" (Timaeus 27d-28a), but such knowledge is the privilege of the gods and of a small number of their friends (Phaedrus 278d). ${ }^{28}$

Evidently the kabbalists were among these friends of the gods, and their lore was the true science of the divine. In Hebrew, Kabbalah was often referred to as a science (חכמה) — or "scienza," for example, in the Italian writings of kabbalist R. Eliyyà Menahem Halfan, who himself fashioned a complex 'ilan. ${ }^{29}$ Many learned Christians accepted and even promoted such an understanding, perhaps none more famously than Pico della Mirandola, who insisted in his Conclusiones, "Nulla est sciencia, que nos magis certificet de diuinitate Christi, quam magia et cabala" (There is no science that more greatly certifies the divinity of Christ than magic and Kabbalah). ${ }^{30}$

I emphasize this point to set up my central argument here, namely that in visualizing the sefirot both conceptually and graphically, medieval kabbalists appropriated - not inappropriately! - the dominant schemata of what Barbara Obrist describes as the "two basic disciplines involved in elaborating models of the universe, astronomy and natural philosophy." ${ }^{31}$ Astronomy provided the nested concentric circle schema of the sefirot in evidence in a Parma manuscript dating to $1286 .{ }^{32}$ Even more prevalent, however, are the arboreal diagrams associated with natural philosophy - so favored, in fact, that they ultimately gave rise to the

Isaac the Blind's Commentary on Sefer Yezirah, Translation and Annotation" (Ph.D. diss., Harvard University, 1994). Notable among recent studies to take up these questions is Jonathan Dauber, Knowledge of God and the Development of Early Kabbalah (Leiden: Brill, 2012). See also Boaz Huss, "Mysticism versus Philosophy in Kabbalistic literature," Micrologus 9 (2001) 125-35.

${ }^{28}$ See Hava Tirosh-Samuelson, "Kabbalah and Science in the Middle Ages," in Science in Medieval Jewish Cultures (ed. Gad Freudenthal; Cambridge: Cambridge University Press, 2012) $476-510$, at 479.

${ }^{29}$ See Fabrizio Lelli, "L'Albero Sefirotico di Eliyyà Menahem Ben Abba Mari Halfan (Ms. Firenze, Biblioteca Medicea Laurenziana, Plut. 44,18)," Rinascimento 48 (2008) 271-90, at 279.

${ }^{30}$ Giovanni Pico Della Mirandola: Conclusiones Sive Theses DCCCC (1486) (ed. Bohdan Kieszkowski; Geneva: Droz, 1973) 79. See the discussion in Bernard McGinn, "Cabalists and Christians: Reflections on Cabala in Medieval and Renaissance Thought," in Jewish Christians and Christian Jews: From the Renaissance to the Enlightenment (ed. Richard H. Popkin and Gordon M. Weiner; Dordrechet, Netherlands: Springer, 1994) 11-34, at 17-21.

${ }^{31}$ Obrist, "The Idea of a Spherical Universe and Its Visualization in the Earlier Middle Ages," 230. Cf. the discussion in Busi, Qabbalah Visiva, 76-83, 95-96.

${ }^{32}$ Parma, Biblioteca Palatina, ms parmense 2784, c. 43r. See Busi, Qabbalah Visiva, 134; Segol, Word and Image in Medieval Kabbalah, 84. 
metonymic appellation "tree" (אילן) for kabbalistic diagrams, regardless of the actual schema deployed.

\section{Establishing the True Constellation of the Godhead}

Roughly three hundred years after the literary emergence of Kabbalah, its classical period was crowned by the masterful survey Pardes rimmonim (Pomegranate Orchard), penned by the brilliant young kabbalist, R. Moses Cordovero. ${ }^{33}$ Cordovero's Pardes, completed in 1548, is an opinionated survey, an inventory with an attitude, but it is no less a valiant work of cultural preservation undertaken by a man whose very name proclaims his Cordovan origins and Iberian refugee status. ${ }^{34}$ Cordovero's ambitious aspiration to collate the entirety of kabbalistic speculation in the aftermath of historical rupture and displacement bears a striking resemblance to the project of the Beyt Yosef (House of Joseph), the comprehensive and critical survey of Jewish law composed by R. Joseph Karo, Cordovero's contemporary and neighbor in the Upper Galilean town of Safed in the mid-sixteenth century. ${ }^{35}$ As part of his summa, Cordovero included a critical inventory of sefirotic iconography that will serve to structure and generate much of the following discussion. Cordovero's work was hardly the first to survey the various opinions regarding the correct visualization of the sefirot, but was of unequaled brilliance, breadth, and influence. ${ }^{36}$

The first five sections or "gates" of the Pardes are devoted to theological and polemical considerations pertaining to the sefirot. With "Gate Six: The Order of Their Array," ${ }^{37}$ Cordovero turns his attention to the graphical visualization of their structure, opening the first of eight chapters devoted to the subject with the following passage: “Chapter One: treating the forms (צורות) of the sefirot, regarding the order of their array (סדר עמידתן-the title of this "gate" of the Pardes): the opinions are manifold. And the kabbalists have drawn forms for themselves on

${ }^{33}$ Moses Cordovero, Pardes rimmonim (Cracow 1592) (Hebrew). On Cordoverian Kabbalah, see Bracha Sack, In the Gates of the Kabbalah of R. Moses Cordovero (Beer-Sheva: Ben-Gurion University of the Negev Press, 1995) (Hebrew).

${ }^{34}$ Paul Fenton's description of Cordovero as the last representative of a western (Spanish and Provencal) school that harmonistically integrated philosophy and Kabbalah is salient here. See Paul B. Fenton, "Joseph Ibn Waqâr and His Attempt to Reconcile Kabbalah and Philosophy," Judaica Petropolitana 3 (2014) 80-98, at 86.

${ }^{35}$ See Yisrael M. Ta-Shma, "R. Joseph Karo and His Work Beyt Yosef-Between Ashkenaz and Sefarad," in Morě̌et Sefarad: The Sephardi Legacy (ed. Haim Beinart; Jerusalem: Magnes Press, 1992) 524-34 (Hebrew).

${ }^{36}$ By the late thirteenth century, kabbalists were sketching line-ups of alternative diagrammatic arrays of the sefirot. See J. H. Chajes, "The Kabbalistic Tree," in The Visualization of Knowledge in the Middle Ages and the Early Modern Period (ed. Marcia Kupfer, Adam Cohen, and J. H. Chajes; Studies in the Visual Cultures of the Middle Ages 16; Turnhout: Brepols, 2020) 449-73.

${ }^{37}$ R. Menachem Azariah da Fano (1548-1620), Cordovero's supportive Italian student, composed an interpretive précis of the Pardes entitled Pelah harimmon (Pomegranate Slice), in which he renamed this section "Gate of the Drawing/Visualization of the Tree" (שער ציור האילן). See the first version of the work - extant only in manuscripts - e.g., Mantova - Comunita Israelitica MS ebr. 127 54a. 
parchments (יריעות) and called them 'tree' (אילן)."38 There is no timeless taxonomy for the nonfigural schematic representations of concepts, and indeed a primary task of the historian of these sources is to be attentive to their specific iconographical terminology, while being self-aware with regard to the implicit claims made by the language we use - for example "diagrams" or "drawings" - in our own interrogations. ${ }^{39}$ Thus the passage adduced at the opening of the present essay used the term siyyurim (ציורים), in that context meaning "drawings," to refer both to mental images (Denkbilder) and to the material images (Abbilder) to be fashioned by the adept. The Hebrew root צ-צ was used in classical rabbinic sources almost exclusively in the latter, material — and even specifically diagrammatic — sense, but came in medieval philosophical sources to mean primarily the former, conceptual sense. ${ }^{40}$ Here, Cordovero uses the term șurah (צורה), used commonly in medieval Jewish philosophy for "form" - in both Platonic and Aristotelian senses. By Cordovero's time it was commonly used by kabbalists to refer to cosmological — and specifically sefirotic - drawings. ${ }^{41}$ As in the opening passage, here too we find the identical term deployed for mental and material images.

Cordovero tells us that by the "forms" of the sefirot he means their visualized configuration, their array-literally, "the order of their standing" (סדר עמידתן). In medieval philosophical Hebrew, "standing" (עמידה) was a term for existence or reality, but Cordovero evokes the usage found in astronomical treatises, where forms of the Hebrew root are used in the sense of "position," specifically the positions of the planets. ${ }^{42}$ The unselfconscious use of astronomical terminology in presentations of kabbalistic theosophy is in evidence in another frequent usage to describe the sefirotic array current from the late thirteenth century: "constellation" (מערכת), as in the foundational work Ma'areket ha'elohut (Constellation of the Godhead), composed in late thirteenth or early fourteenth-century Spain. ${ }^{43}$ Sefirotic

${ }^{38}$ Cordovero, Pardes rimmonim, 34c.

${ }^{39}$ See Faith Wallis, "What a Medieval Diagram Shows: A Case Study of Computus," Studies in Iconography 36 (2015) 1-40, at 1-3.

${ }^{40}$ See Lelli, "Osservazioni sull'uso del termine siyyur"; Moshe Idel, "Visualization of Colors, I: David Ben Yehudah He-Hasid's Kabbalistic Diagram," Ars Judaica 11 (2015) 31-54, at 41-43.

${ }^{41}$ For a wonderful example, see J. H. Chajes and Eliezer Baumgarten, The Booklet of Kabbalistic Forms: An Introduction, Facsimile, Critical Edition and Commentary (Rome: Biblioteca Apostolica Vaticana, forthcoming).

${ }^{42}$ For example, in the works of the twelfth-century Spanish philosopher R. Abraham Bar Hiyya's Surat ha'ares (Offenbach, 1720) (Hebrew). Scholem noted the usage העמדה in the writings of R. Shem Tov ibn Gaon (c. 1310), which he understood in the sense of "existence." Gershom Scholem, "Śeridey sifro šel R. Shem Tovibn Ga'on 'al yesodot torat hasefirot," Qiryat Sefer 9 (1933) 126-33, at $128 \mathrm{n} .1$ (Hebrew). The early fourteenth-century treatise on the sefirot, Sefer haššem, uses the related terminology seder ma 'amadan and maqom ma 'amadan. Michal Oron, Sefer Hǎ̌šem: Attributed to R. Moses De León, (Los Angeles: Cherub Press, 2010) 59 (Hebrew).

${ }^{43}$ In this work, the discussion of the positions of the sefirot is found in the seventh chapter, "constellation of the order" (מערכת הסדר), under the heading "the order of the drawing (or "visualization") of the place of the sefirot" (סדר ציור מקום הספירות). The term מערכת could also mean "geometric proportion." See Jacob Klatzkin, Thesaurus Philosophicus (Berlin: Eschkol, 1933) 241-242, s.v. 
constellations (מערכות) are equated with 'ilanot in a telling passage from Cordovero's commentary on the Zohar that reveals the profoundly cosmological-ontological character of its kabbalistic appropriation:

With regard to the reality of the sequence of levels (השתלשלות המדרגות) from above to below, they are without end, and they are stations (מחרכות), constellations opposite constellations (מערכות מול מערכות), and the constellations emerge in sequence one from another, and each and every constellation will now be called "tree" (אילן). And I have already explained that the constellation of 'Asilut (Emanation - the highest of the four "worlds") is the 'ilan of 'Așilut, and no (demonic) shell will rule it whatsoever. After it, the constellation of the 'ilan of Briyah (Creation - the second of the four worlds), this constellation being a shell and garment to 'Așilut. ${ }^{44}$

'Ilan, the very same term that Cordovero has singled out as denominating the inscription of an arboreal diagram on parchment, is here linguistically - and ontologically - assimilated into his astronomically inflected summary of the emanatory process. ${ }^{45}$ The term ma 'areket (מערכת) refers in medieval Hebrew sources specifically to the order and array (recalling the title of the section of the Pardes under consideration) of a group of stars, otherwise known as a mazzal (מזל). term mahaneh (מחנה) refers to a so-called "lunar mansion/station/house," being one of the twenty-eight segments of the ecliptic used to track the movement of the moon relative to the "fixed stars." ${ }^{47}$ I stress the unselfconscious usage of this astronomical terminology because from the perspective of discursive analysis, it is, in fact, much more significant than intentional borrowings as an indicator of profound implication; it is how they speak rather than what they speak about.

If the arboreal schema is a constellation, parchment is the sky. Cordovero's opening definition of an 'ilan places equal emphasis upon its medium, a yeri 'ah

מערכה, מערכת. Cf. Cordovero's use of the expression "assembly (קיבוץ) of the sefirot" in the Pardes, Gates 13 (3) and 23 (6). "Assembly" (קיבוץ) is a term that was also widely used for constellations of stars. In Gate 13 (3), Cordovero identifies "assembly of the sefirot" with the "supernal station" - _ - about which, see below.

${ }^{44}$ Cordovero, 'Or Yaqar (Vol. 3: Tiqqunei ha-zohar; Jerusalem, 1964) 88b.

${ }^{45}$ In 'ilan scrolls, the division into four worlds is primarily seen in Lurianic artifacts, referring to the schools that emerged from Cordovero's successor in Safed, R. Isaac Luria (1534-1572). In these Lurianic 'ilanot, each world is often represented with an array of arboreal diagrams, recalling Cordovero's usage in the adduced passage. Scrolls that reflect primarily Cordoverian influence, such as those produced in Yemen and Kurdistan, represent the four worlds but use the term "chariot" rather than 'ilan to refer to the schematic representation of each world. On these scrolls, see Eliezer Baumgarten, Uri Safrai, and J. H. Chajes, "See the Whole World in the Likeness of a Ladder': A Kabbalistic Ilan by R. Joshua ben David of Kurdistan," in Benayahu Memorial Book (ed. Moshe Bar-Asher et al.; Jerusalem: Carmel, 2019) 843-72.

46 The term mazzal (מזל) most frequently refers to the constellations of the Zodiac and, by extension, to their astrological influence. In the thirteenth-century kabbalistic classic Ša 'arey 'orah (Gates of Light), to which I will return below, "supernal mazzal" (מזל עליון) is among the names given to the highest of the sefirot (keter, or crown).

${ }^{47}$ See Klatzkin, Thesaurus Philosophicus, s.v. מחנה and מערכת and. 


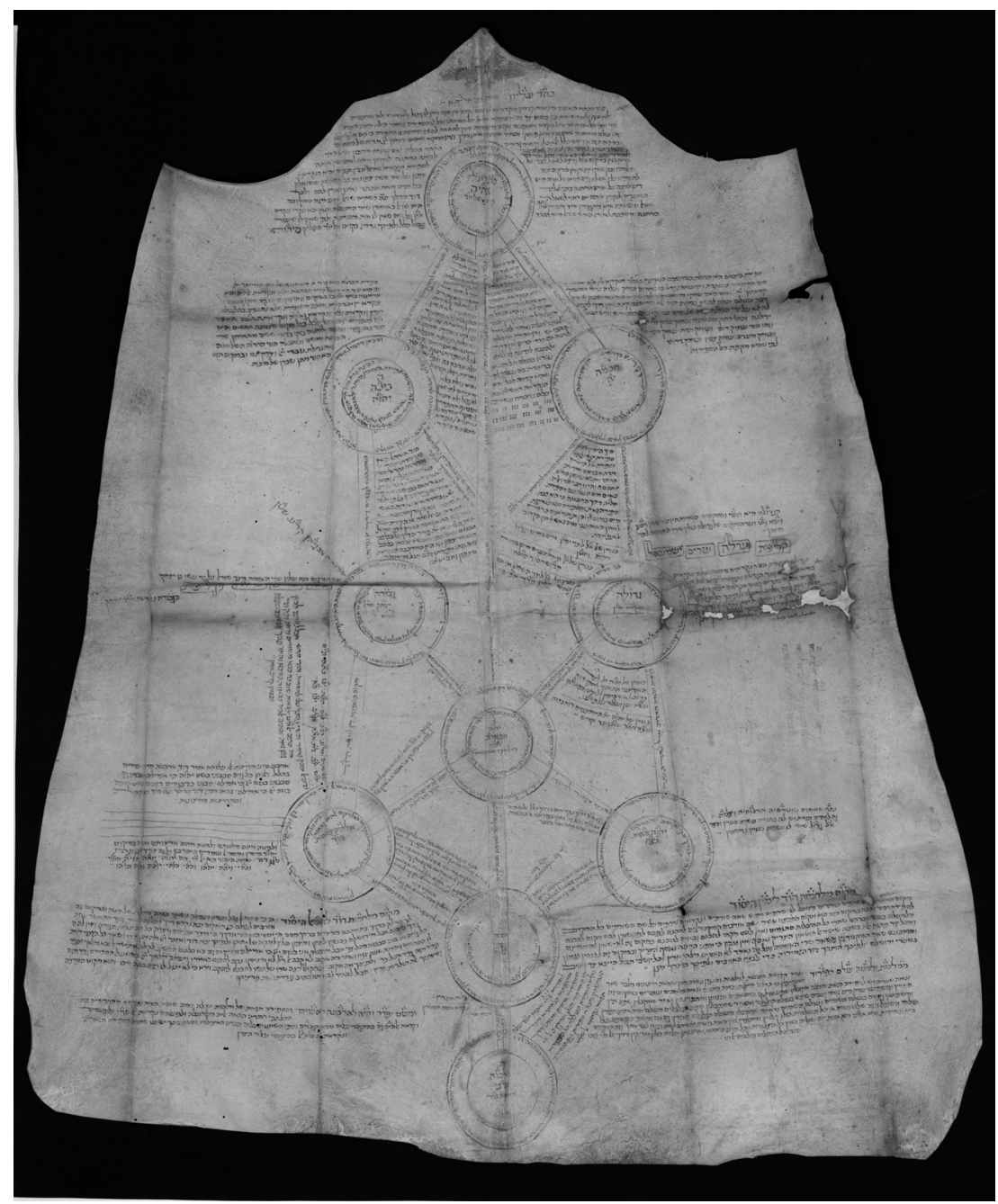

Figure 2: Vatican City, Biblioteca Apostolica Vaticana, MS Vat. ebr. 530 III. Reproduced with permission from Dr. Delio Proverbio, Curatorof Oriental Manuscripts, Biblioteca Apostolica Vaticana.

(יריעה). The term immediately recalls Psalms 104:2, "who stretchest out the heavens like a curtain," a biblical verse ubiquitous in kabbalistic sources, as well as a famous dictum of R. Yohanan ben Zakkai, "If all the heavens were parchment (יריעות), and all the trees (אילנות) pens, and all the seas ink, it would be insufficient to write the wisdom I learned from my teachers." ${ }^{48}$ If the term yeri 'ah in the opening passage is primarily an indicator of material, by Cordovero's time it was the long-standing

${ }^{48}$ Adduced in the talmudic tractate devoted chiefly to the scribal arts, Maseket sofrim (Tractate of Scribes) 16:8. 


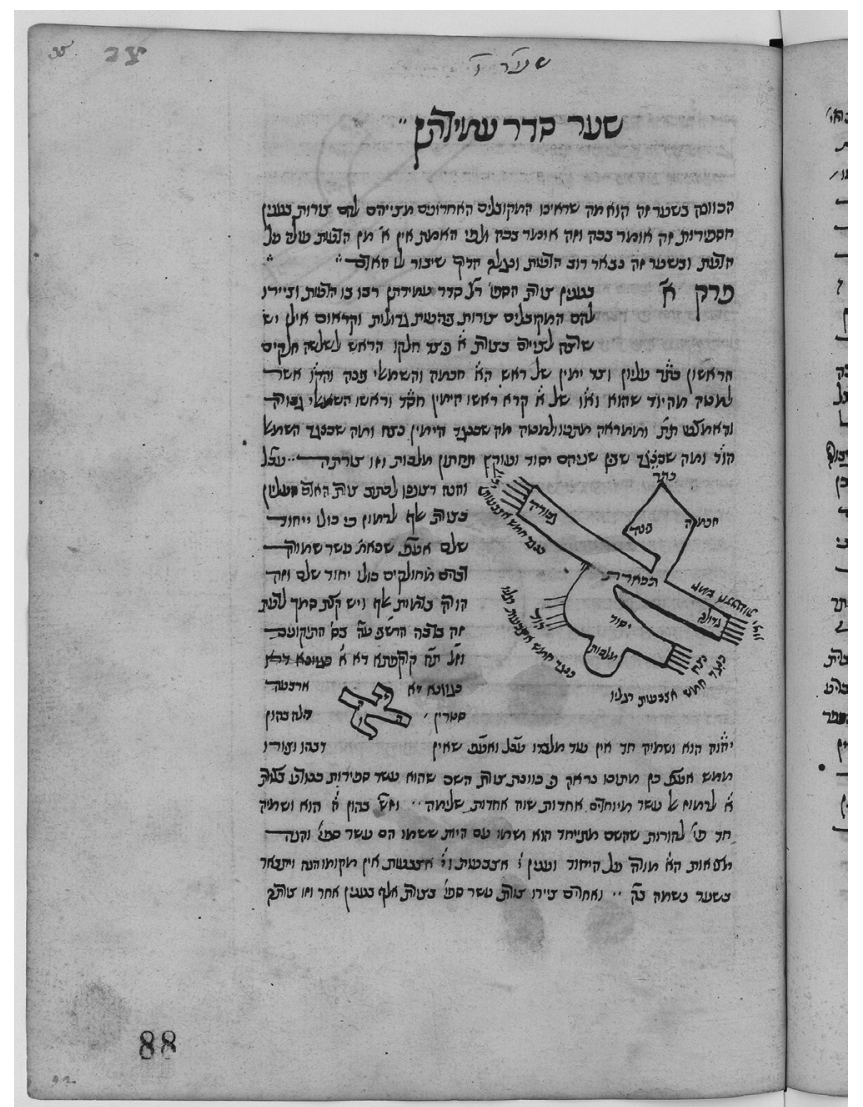

Figure 3: Vatican City, Biblioteca Apostolica Vaticana, MS Neofiti 28, 88r. Reproduced with permission from Dr. Delio Proverbio, Curator of Oriental Manuscripts, Biblioteca Apostolica Vaticana.

metonym used to refer to a large-format inscribed sefirotic diagram. ${ }^{49}$ A number of such single-sheet parchments dating to the fourteenth and fifteenth centuries, including artifacts that appear to be of Italian, Byzantine, and pre-expulsion Spanish provenance, have reached us [Figure 2]..$^{50}$ These were certainly what Cordovero had in mind when he wrote that the kabbalists call the inscription of the forms of the sefirot on a parchment sheet an 'ilan, an arbor. ${ }^{51}$

The first diagrammatic treatment of the sefirot considered by Cordovero visualizes their array in the form of an alef ( $)$, the first of the 22 Hebrew letters. "There were those who wanted to draw them in the form of an alef," he begins

${ }^{49}$ See the last line of Cordovero, Pardes rimmonim 9:2.

${ }^{50}$ Examples include Vatican MS ebr.530 III and Biblioteca Queriniana MS L FI 11, the latter recently brought to my attention by my kind and erudite cousin, Dr. Evelien Chayes.

${ }^{51}$ On the significance of the media of 'ilanot, see J. H. Chajes, "The Kabbalistic Ilan as Material Text," Henoch (forthcoming). 
[Figure 3]. ${ }^{52}$ Cordovero explains this configuration as having the shape of the first Hebrew letter, which consists of three components; three sefirot are embedded in each. The alef diagram in an early Pardes manuscript is in keeping with the verbal description, though not limited by it. ${ }^{53}$ In addition to displaying the names of the sefirot in their locations, the diagram adds fingers and toes of uniform length to the crossbar and foot of the letter. The protrusion extending between the legs of the alef is labelled Malkut (Kingdom), the last and exclusively receptive sefirah, and hangs beneath Yesod (Foundation), the latter normally the Kabbalah's great phallic symbol. Thanks to these anthropomorphic elaborations, the diagram better exemplifies the principle that Cordovero regards as implicit in this visualization: "Their intention was to write the forms of the Supernal Adam in the form of alef to suggest that despite its divisions it is entirely one whole unity." ${ }^{54}$ These same visual elements, to which there is no reference in Cordovero's text, also evoke the axiomatic dictum of Sefer yeșirah, according to which the sefirot are arrayed like fulcra and scales in two opposing sets of five, like fingers and toes. ${ }^{55}$

Significantly, Cordovero emphasizes that although the image communicates the important concept of divine unity-despite-plurality, it should not be taken as an accurate representation of the real structure of the divine realm. ${ }^{56}$ Twice Cordovero writes that the drawing should not be taken as "real"- -he uses the term mamaš (ממש) - and that the kabbalists did not mean to imply that the structure

${ }^{52}$ Cordovero's alef is rather different from the cosmological alef in the early kabbalistic work Sefer ha' orah (Book of Light) as found in a fifteenth-century manuscript, but the latter too is meant to represent "the sublime form" (צורה מעולה). See Busi, Qabbalah Visiva, 110-13.

${ }^{53}$ Vatican MS Neofiti 28 includes the author's colophon dated 29 Av 5308=1548, but was likely copied from an autograph somewhat later. The hand closely resembles that found in the Pardes rimmonim fragment found in Cod. Parma 3462, which was copied in Safed by Cordovero's student Abraham Galante in 1561. The latter unfortunately begins with the later lexographical chapter, $\breve{S}$ a 'ar hakkinuyim. Dr. Emma Abate kindly informed me of the author's colophon also copied in Cordovero's Zohar commentary, 'Or yaqar, extant as Modena Biblioteca Estense Cod. $\alpha$ L. 1, vol. 5, 450r. And see also the similar hand in a manuscript thought to be a Cordovero autograph in the Chabad Library, described in Mibeis Hagenozim: Treasures From the Chabad Library (ed. Shalom Dovber Levine; Brooklyn: Kehot, 2009) 225-26. Cordovero's signature on a legal ruling from 1562 preserved in Marseille MS 1226, however, shows a markedly different hand. Cordovero's diagrams were faithfully reproduced in the first printed edition (Cracow, 1592), with minor exceptions to be noted in what follows. The alef diagrams of the Pardes were adapted by Athanasius Kircher in his Oedipus Aegyptiacus (Rome, 1652-54), tom. 2, vol. 1, 302 (https://goo.gl/i7Psiv). Kircher used Vatican MS Neofiti 28, and his marginal notes are found throughout. See Daniel Stolzenberg, Egyptian Oedipus: Athanasius Kircher and the Secrets of Antiquity (Chicago: The University of Chicago Press, 2013) 169-74.

${ }^{54}$ Cordovero, Pardes rimmonim, 33c.

${ }^{55}$ Hayman, Sefer Yeșira, 67 ( $\left.\$ 3 \mathrm{~K}\right)$ : “The ten sefirot are the basis-like the number of the ten figures, five opposite five, and the covenant of the Unique One is exactly in the middle in the covenant of the tongue and the circumcision of the flesh." This visualization is undeniably difficult to reconcile with identifications of the sefirot elsewhere in the short work.

${ }^{56}$ The notion that the figure (תמונה) of the sefirot was the model of the universe, understood in Platonic geometric-architectonic terms, was central to classical Geronese Kabbalah. See the salient remarks to this effect in Tirosh-Samuelson, "Kabbalah and Science in the Middle Ages," 504 n. 150. 


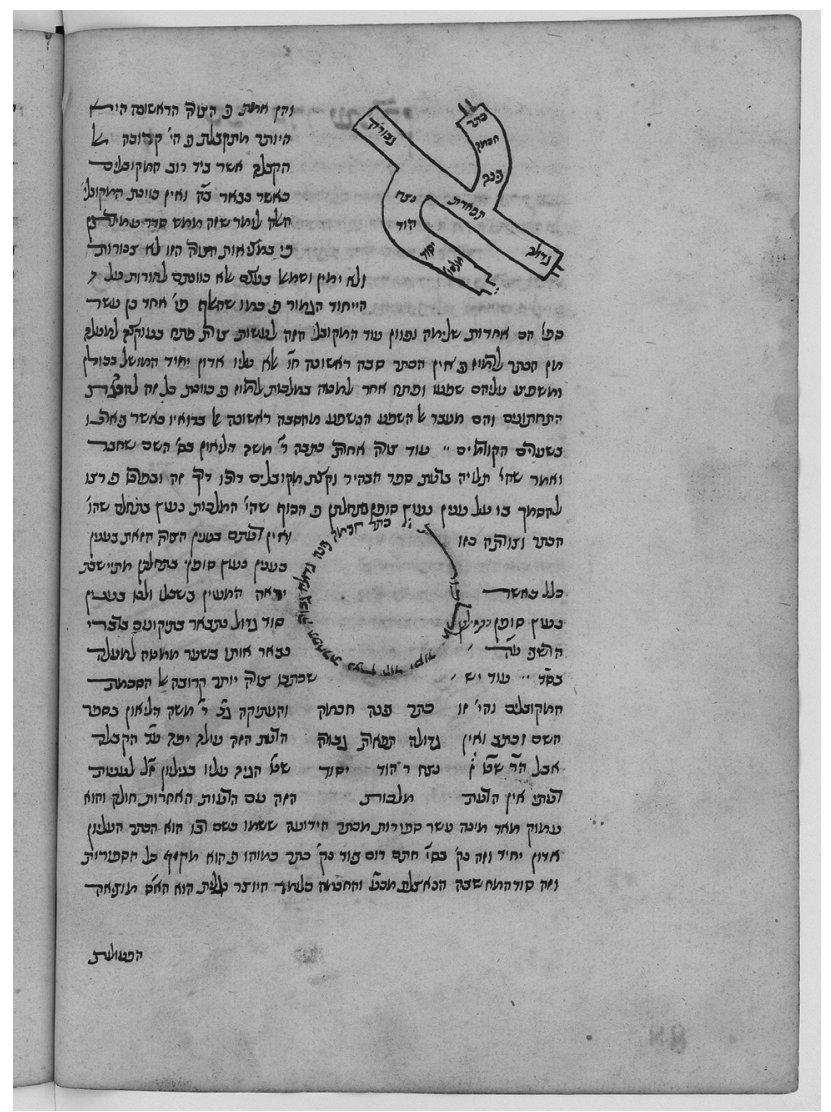

Figure 4: Vatican City, Biblioteca Apostolica Vaticana, MS Neofiti $2888 v$. Reproduced with permission from Dr. Delio Proverbio, Curator of Oriental Manuscripts, Biblioteca Apostolica Vaticana.

of the Godhead was captured by the form of this letter: "It is not the intention of these kabbalists to say that this is the real (ממש) secret of their existence, because in reality (במציאות) this form has no channels (צינורות) and no right or left." ${ }^{57}$ The 'ilan must resemble its referent; in Peircean terms, Cordovero insists that the 'ilan is an iconic rather than symbolic sign; it "physically" resembles and is not merely customarily associated with that which it signifies. ${ }^{58}$ For Cordovero, only the

${ }^{57}$ It is perhaps though by no means necessarily ironic that the term mamaš was originally used in medieval Jewish thought to denote primary substance, the very same substantia of the Porphyrian trees that became the de rigueur diagrams in medieval manuscripts of the Isagoge, or Introduction to Aristotle's Categories.

${ }^{58}$ For a recent review of the art historical adoption of Peirce's semiotic classifications, see Michael Hatt and Charlotte Klonk, Art History: A Critical Introduction to Its Methods (Manchester: Manchester University Press, 2006) 208-12. 


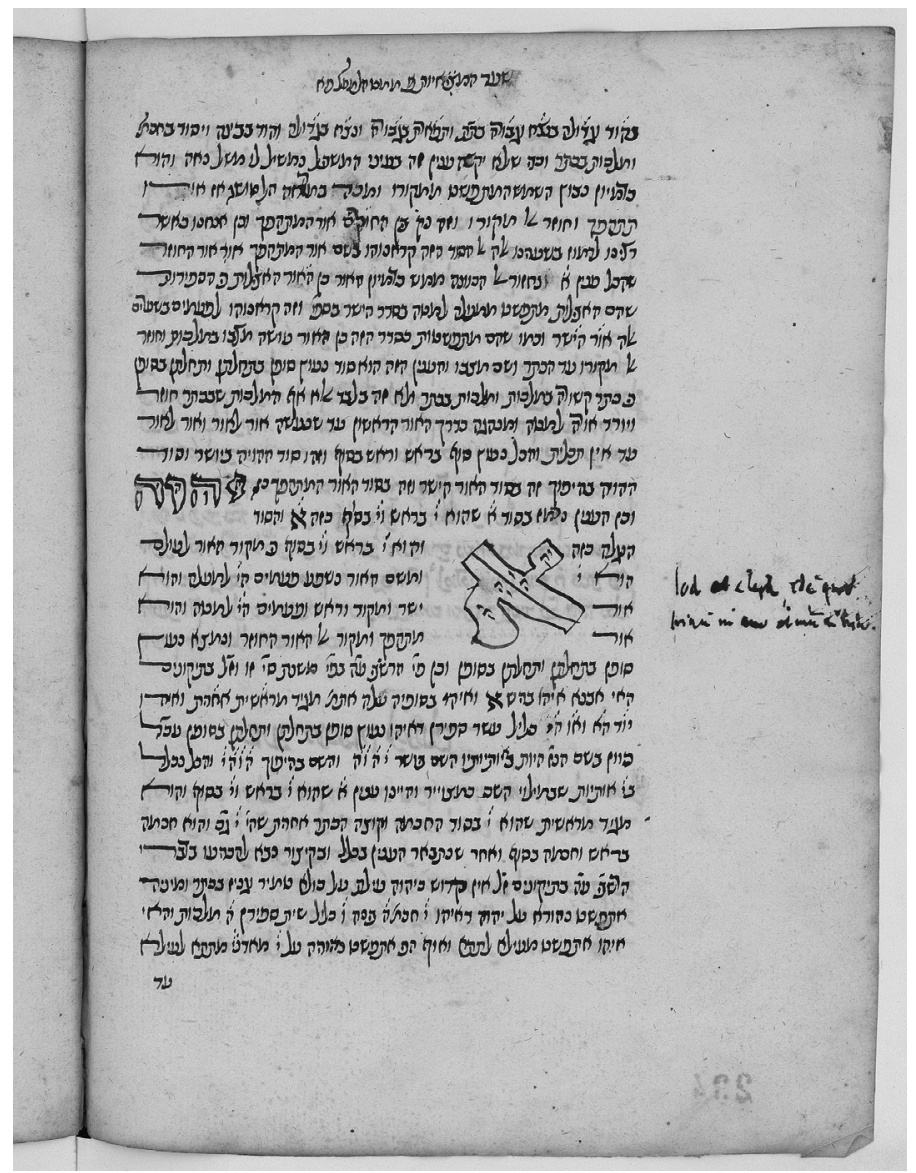

Figure 5: Vatican City, Biblioteca Apostolica Vaticana, MS Vat Neofiti $28234 \mathrm{v}$. Reproduced with permission from Dr. Delio Proverbio, Curator of Oriental Manuscripts, Biblioteca Apostolica Vaticana.

exceptional kabbalistic diagram is "merely" a symbol that does not provide visual representation of the topography of the Godhead.

Cordovero follows this with a consideration of a second form, which he hastily and rather disdainfully rejects, despite its impressive pedigree [Figure 4]..$^{59}$ This form is meant to convey another characteristic of the sefirot, again based on a passage in Sefer yesirah: "Their end is fixed in their beginning. ${ }^{"{ }^{00}}$ Cordovero's dismissal of the visualization of this principle as a circle, with the names of the sefirot arrayed like the hours on a clock, was absolute, his disdain an expression of his conviction that a profound categorical error had been made. The characteristic of the sefirot expressed

${ }^{59}$ Cordovero writes that it is found in a manuscript of Moshe de Leon based, according to the latter, on Sefer habbahir.

${ }^{60}$ Hayman, Sefer Yeșira, 74 (§6). 
in the passage of Sefer yesirah, he would explain elsewhere, refers not to structure but to process. ${ }^{61}$ The sefirot are not arrayed in a circle, but emanate in a sequence that ultimately reflects back upon itself, in Cordovero's metaphor, "like sunlight off a mirror." 62 This "is called reflected light (אור המתהפך) by scientists (חוקרים)," he tells his reader-not missing an opportunity to link Kabbalah and science, in this case, optics. Ultimately, this principle is possible to visualize symbolicallywhich is precisely what he does in "Gate 14"

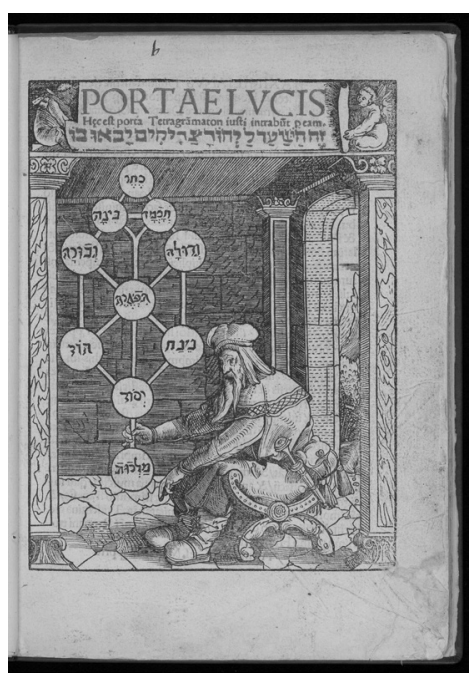

Figure 6: Portae Lucis frontispiece, Courtesy of the Embassy of the Free Mind, Bibliotheca Philosophica Hermetica Collection. [Figure 5] — but heaven forfend that symbolic and iconic representations of the sefirot be confused! Cordovero's condemnation of this representation was so strong that the publisher of the first edition, who took the diagrams of the Pardes very seriously, deemed it reasonable to omit, thus saving himself a small typesetting headache. In its place, we find in parenthesis, "Said the typesetter (מגיה), the reader (המעיין) should draw (יצייר) ten sefirot in one circle and find that the beginning of the circle is Keter and the end of the circle Malkut beside Keter." It suffices for the reader to picture this (faulty) image in his mind's eye.

With assurances that he will ultimately provide the true explanation of this principle, Cordovero quickly proceeds to his third "form" - this time one "close to consensus amongst kabbalists." This boxy array, he notes, was copied by the thirteenth-century Castilian kabbalist R. Moshe de Leon, despite the latter's critique of its accuracy. The form favored by Cordovero and, he states, all kabbalists is one familiar to many today from the oft-reproduced wood-cut titlepage of Paulus Ricius' Portae Lucis (Augsberg, 1516), the Latin translation of the thirteenth-century Castilian R. Joseph Gikatilla's Ša 'arey 'Orah [Figure 6]. ${ }^{63}$ In addition to de Leon, the great Spanish refugee kabbalist R. Judah Hayyat favored it, the latter coining the descriptive "segolta segol segol" to capture its form by referencing the names of particular paratextual symbols used for the cantillation and vocalization of the Torah, something like a three-pointed delta followed by two

${ }^{61}$ Gate 14: $\check{S}$ a'ar mimmatțah lema 'alah [Gate from Below to Above]. Cordovero, Pardes rimmonim, 89b-92a.

${ }^{62}$ The doctrine is detailed in Yoseph Ben Shlomo, The Doctrine of God of R. Moses Cordovero (Jerusalem, 1965) 270 (Hebrew).

${ }^{63}$ On recent attempts to identify the artist responsible for the woodcut, as well as of the figure pictured contemplating the tree, see Saverio Campanini, "Aperçu sur la Représentation de l'Arbre des Sephiroth dans la Kabbale Chrétienne," Points de Vue Initiatiques 179 (2016) 48-67, at 52-54. Campanini thinks it most probable that the figure is Ricius. 


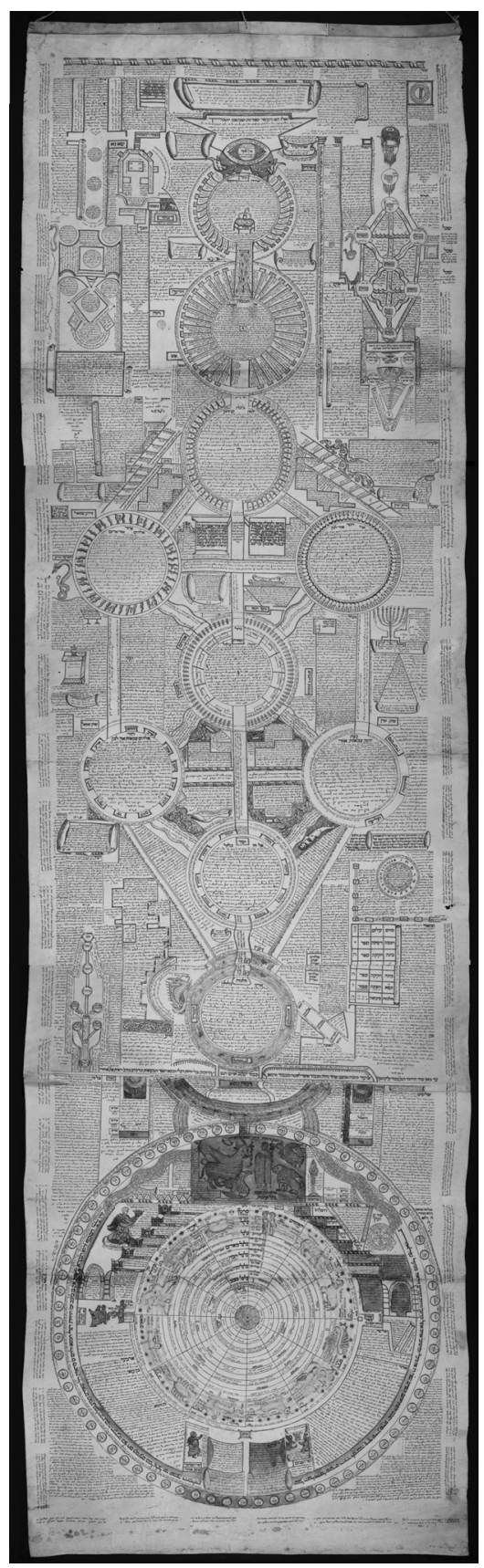

Figure 7: Oxford - Bodleian Library MS Hunt. Add. D (Neubauer 1949). Reproduced with permission from The Bodleian Libraries, The University of Oxford. 
three-pointed nablas.$^{64}$ The points are as significant here as the triangle and inverted triangle shapes, as each corresponds precisely to one of the sefirot. Moreover, this particular configuration accurately represents the relative positions and relations between the sefirot, above and below as well as right, left, and center.

Cordovero has at this stage established what he deems to be the correct configuration of the sefirot, though his work is far from complete. At the time of his writing, various alternative visualizations — variations really—some with illustrious pedigrees, were in use. ${ }^{65}$ One such variation aligned the first three sefirot centrally rather than triangulating them. The right and left of the triangular configuration, it was argued, could hardly apply to these most sublime nodes of the divine. Endorsed by the late thirteenth-century kabbalist R. Isaac of Acre in his Me'irat 'eynayim, this schema may be seen in the greatest of all 'ilanot produced in the decades preceding Cordovero's activity [Figure 7].

In this "Magnificent Parchment," the tree-as a kind of kabbalistic empyreanrises above the Throne of Glory, which itself hovers above a detailed and richly illuminated cosmograph of the spheres ${ }^{66}$ This schema, popular in Italy at the time, was not Cordovero's preferred form, but neither did he find it overly objectionable. He reserves his invective for a configuration that had been endorsed by no few authorities in which the sefirot typically on the right were placed on the left, and vice versa. ${ }^{67}$ This reversed configuration had been endorsed by $R$. Isaac as well as nothing less than the "true configuration" (העמדתן הנכונה האמיתית).

The discussion of this disturbing variation-disturbing especially given the loaded symbolic connotations of left and right - also highlighted the more general theological difficulties inherent in Cordovero's critical review. On the one hand, its stated goal was to establish the "true" configuration of the Godhead, with every sefirah in its right place: right, left, center, up, and down. On the other, such a spatial discourse effectively materialized the Godhead. Assertions that this language was metaphorical have an air of apologetic desperation: right and left refer to qualities rather than sides, up and down to causal relationships rather than to relative altitude. The reversal also provoked reflection on the salient question of perspective: whose point of view is implied in the sefirotic tree? Is the "right" column God's right, or

${ }^{64}$ Cordovero attributes this mnemonic formula to Hayyat in the Pardes, Gate $6 \mathrm{ch}$. 1. It may be found in Hayyat's Minhat Yehudah commentary in Ma'areket ha'elohut, (Jerusalem: Y. Beker, 2013) 11b. The association between these vowel points and the sefirot is found in the introduction to the early fourteenth-century Tiqquney zohar, adduced by Hayyat.

${ }^{65}$ See Scholem, "Śeridey sifro šel R. Shem Tov ibn Ga'on," 1933 (8), 534.

${ }^{66}$ See above, n. 9. See also Chajes, "The Kabbalistic Tree"; Busi, Qabbalah Visiva, 384-88. For another tree rising above lower worlds, see Paris MS 843 79a. https://goo.gl/5RnXr2. That diagram labels the worlds beneath the tree as World of the Chariots, World of the Angels, World of the Intellects, and World of Nature.

${ }^{67}$ Cordovero offers a benevolent reading of the right-left reversal elsewhere in the Pardes, including Gate 7:2 and 9:2. In both of these discussions, Cordovero specifically mentions the representation of this position in 'ilanot as opposed to purely textual deliberations.

${ }^{68}$ Goldreich, "Sefer me'irat 'eynayim," 120. 
our right, i.e., heraldic left? Are we facing God or adopting God's view? Cordovero, emphatically rejecting the reversal, argues that the human form is more shadow than mirror of the divine form, and that shadows do not reverse right and left. He also compares the sefirot to the stone Tablets of the Covenant that were engraved straight through, front to back, but which nevertheless read the same way from either side. The Tablets were, in his extraordinary phrase, "one of the supernal branches of materialized spirituality" in which "there is no right and no left but everything is right and everything is left." ${ }^{69}$ In his kabbalistic prayer book, Cordovero offers something of a compromise: in general, the kabbalist is in a state of identification with the divine, making the right of the kabbalist the right of the divine, and the left, the left. At moments of dissociation, however, the divine becomes other, and the kabbalist's view shifts accordingly. Now the right of the kabbalist is God's left, and the left, the right. ${ }^{70}$

Having established the true "form of the standing of the pure and holy emanation" (צורת עמידת האצילות הטהור והקדוש), in his third sub-chapter Cordovero broadly theorizes his discussion so as better to surmount its theological liabilities. "With regard to this form," he asks, "what is its essence and its function, and what is intended in its drawing (מה מהותה וענינה ומה הכוונה בציורה)?"71 Elaborating on the (apologetic) note just sounded, Cordovero reiterates that the schema, which he has insisted must reflect the array of the sefirot "in reality," is to be understood in causal rather than in spatial terms. The philosophical key that enables this substitution is remarkably simple: every cause encompasses its effect. This medieval philosophical commonplace, found in Proclus, catapults the discussion, albeit ironically, to (outer) space.

The point of the earth is in the middle of the firmament, and the firmament surrounds the earth, and the firmament is the cause of all things under heaven according to the divine will, as is well-known among scientists, (e.g.,) that the movement of the spheres (גלגלים) is the cause of the compounding of the elements. $^{72}$

To understand the sefirot, one must understand the spheres. Perhaps unexpected to some readers, the elision of the sefirot and the spheres in Cordovero's discussion was all but inevitable in light of the common medieval understanding of the latter. Maimonides, invoked here by Cordovero, like Aristotle before him, understood the heavenly bodies to be sentient: "All the stars and spheres possess a soul, knowledge, and intellect. They are alive and stand in recognition of the One who spoke and

${ }^{69}$ Cordovero, Pardes rimmonim, $35 \mathrm{~d}$.

${ }^{70}$ Moses Cordovero, Tefillah leMoshe (Przemys1, 1892) 106a-b. For a striking mirrored representation of the sefirotic structure, captioned "face to face" (פנים כנגד פנים), see Netibot 'emunah by R. Yehya Harizi of Yemen (c1700), National Library of Israel Ms. Heb. 8³896, 83a.

${ }^{71}$ Cordovero, Pardes rimmonim, 35d.

${ }^{72}$ In his Zohar commentary, Cordovero identifies the firmament (ריעיע) with the "Supernal Tree (האילן העליון)." Cordovero, 'Or yaqar, (Vol. 7: Shemot I; Jerusalem, 1975) 3b. See below on the attempts to reconcile cosmological terminologies from biblical, Greek, and kabbalistic traditions. 


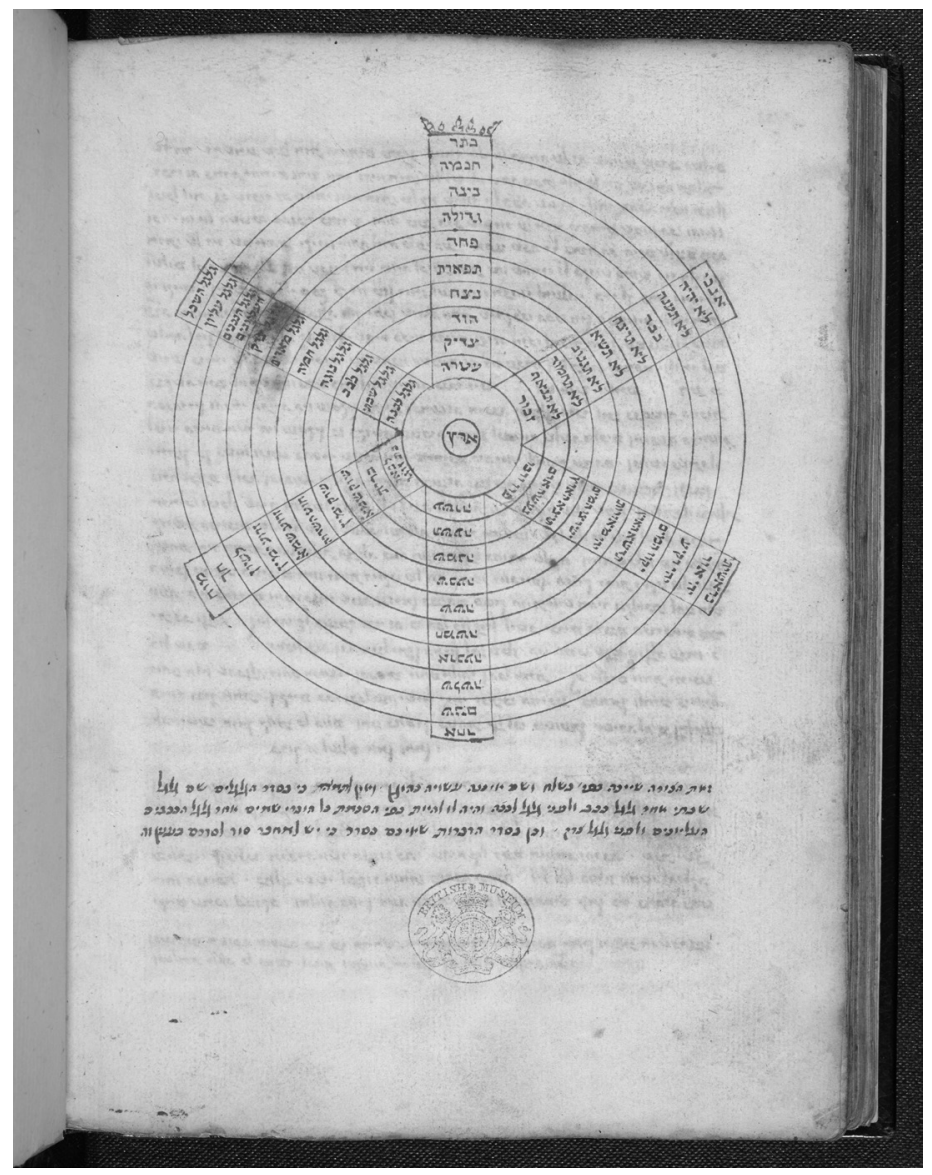

Figure 8: (C) British Library Board (British Library Add MS 27172, 123v); Polonsky Foundation Catalogue of Digitised Hebrew Manuscripts.

[thus brought] the world into being." ${ }^{.73}$ Lest one object that the polarity-driven attraction of the sefirot made them ill-suited for harmonization with the heavenly bodies, we recall that for Aristotle, it was desire (for the Prime Mover) that set the

${ }^{73}$ Maimonides, Mishneh Torah, Hilkot yesodey hattorah, halakah 9. Maimonides was part of a tradition that combined medieval Aristotelian and Platonic elements and posited complex relations between the "intellects" and the planetary spheres. On this tradition, see David R. Blumenthal, Philosophic Mysticism: Studies in Rational Religion (Ramat Gan: Bar-Ilan University Press, 2006); Fenton, “Joseph Ibn Waqâr”; Israel Sandman, “The Məšōbēb Nətībōt of Samuel Ibn Matut ('Motot'): Introductory Excursus, Critical Edition, and Annotated Translation" (PhD diss., University of Chicago, 2006). The kabbalistic treatments of the precise relations between the sefirot and the spheres are indebted to these earlier philosophical discussions, but a detailed examination is beyond the scope of this essay. On Maimonides and classical Kabbalah more generally, see Elliot R. Wolfson, "Beneath the Wings of the Great Eagle: Maimonides and Thirteenth-Century Kabbalah," in Moses Maimonides (1138-1204): His Religious, Scientific, and Philosophical "Wirkungsgeschichte” in Different Cultural Contexts (ed. Görge K. Hasselhoff and Otfried Fraisse; Würzburg: Ergon Verlag, 2004) 209-37. 
spheres in motion. ${ }^{74}$ Of course Cordovero's point was not to conflate spheres and sefirot, but to assert that the resemblance of their visualizations was the result of shared forms of relationality.

In the tradition of Spanish philosophical kabbalists before him, Cordovero was also interested in the correspondences, equations, and relations between the sefirot and other pre-kabbalistic cosmological models. ${ }^{75}$ A diagram in a Me'irat 'eynayim manuscript copied in Italy in 1552 provides visual testimony of this approach [Figure 8]. ${ }^{76}$

In this diagram, we find ten geocentric spheres inscribed so as to establish correlations between them and the ten sefirot (as well as to the Ten Commandments, the ten creative speech-acts of Genesis 1 , and ten key body parts). The fact that the schema deployed was a geocentric rota of the universe is telling. The same correspondences could, after all, have been shown clearly by using a simple table. By inscribing the terms in this specific geometric idiom, however, an implicit argument was being advanced. ${ }^{77}$ It is worth noting that although the inscription "earth" is found at the center of this rota, the central column rising above it is, in fact, devoted to the sefirot. The astronomical spheres, inscribed on the "ten o'clock" diagonal, merely echo them.

A more direct diagrammatic correlation between the spheres and the sefirot may be found in manuscript copies of the 1370 work Mešob $\underline{b} \underline{b}$ netibot, written by R. Samuel ibn Matut in Guadalajara, Spain. In this commentary on Sefer yeșirah, copied repeatedly in sixteenth-century Italy, the author harmonized Greco-Arabic philosophy and Kabbalah. In a section describing the divine flux and its transmission through the sefirot, ibn Matut includes a striking diagram, introduced with the following passage: "And the archetype (דוגמה) (דיכה) as the astronomical (תיכוניות) sefirot, which are the orbs (גלגלים) that we see, namely nine orbs and the lower world and all that is within them" (Cod. Parma MS 3489, 102a). The accompanying diagram on the verso [Figure 9] presents ten concentric

${ }^{74}$ Metaphysics 12.7.1072b.3-4. See Edward Grant, Planets, Stars, and Orbs: The Medieval Cosmos, 1200-1687 (Cambridge: Cambridge University Press, 1994) 515. Cordovero, like so many kabbalists before him, used a Hebrew translation of the preferred medieval moniker for the Prime Mover, causa causarum, to refer to 'Eyn sof: "the sefirot . . . are one above the other because 'Eyn sof the emanator is the cause of causes, whose first effect is Keter" (38a). See also Moshe Idel, Kabbalah and Eros (New Haven: Yale University Press, 2005) 205.

${ }^{75}$ Fenton, "Joseph Ibn Waqâr," 86. Cf. Oded Yisraeli, "Coerced Kabbalist: R. Judah ben Yakar —Between the Man and his Image," Kabbalah 31 (2014): 281-309, esp. 294-295 (Hebrew), emphasizing Yisraeli's assertion of the absolute distinction between the cosmological conception and the theosophical conception of Provencal and Gerona kabbalists.

${ }^{76} \mathrm{https} / / /$ goo.gl/An5Uik (the diagram); https://goo.gl/KDXjYz (the NLI catalogue). Cf. the very similar diagram in the Parma, Biblioteca Palatina, Heb. Ms 2784, fol. 24a, dated to 1286 (though the diagram may have been inscribed later). It is reproduced and discussed in Fenton, "Joseph Ibn Waqâr," 96.

${ }^{77}$ See Michael Evans, "The Geometry of the Mind: Scientific Diagrams and Medieval Thought," Architectural Association Quarterly 12.4 (1980) 32-55; Wallis, "What a Medieval Diagram Shows."

${ }^{78}$ See Klatzkin, Thesaurus Philosophicus, s.v. דוגמה. 


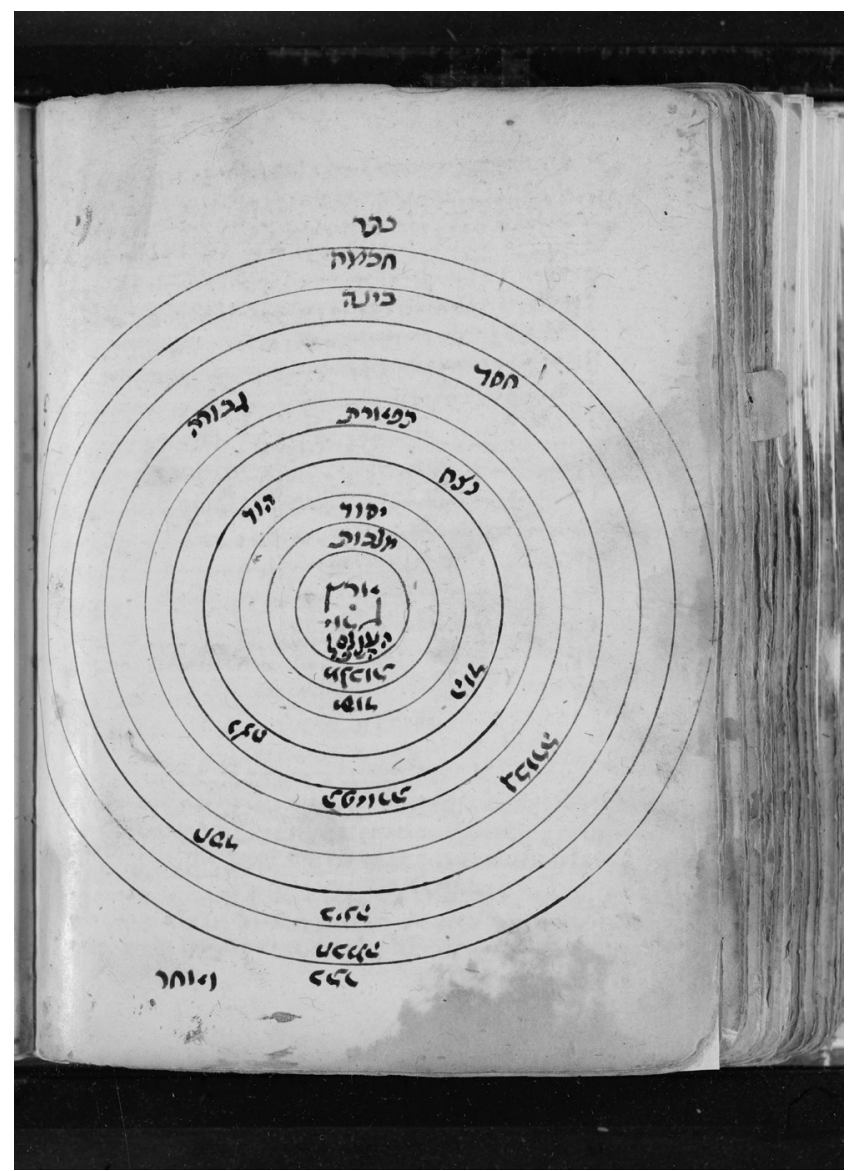

Figure 9: Biblioteca Palatina, Cod. Parma MS 3489, 102v, under concession by the Ministry for Cultural Heritage and Activities.

circles that demarcate nine bands surrounding the center circle, labelled "land" (ארץ) and "lower world." The nine bands are not inscribed with planetary names, but with the names of the ten sefirot, the tenth, Keter, placed just beyond the circles. Note the configuration of the first three sefirot as a pillar. What is truly noteworthy for our purposes, however, is the mirroring of the entire superimposed arboreal inscription in the bottom half of the diagram, as often found in astronomical figures. This mirroring emphasizes the sphericity and symmetry of the system.

Gershom Scholem famously insisted that "the term sefirah is not connected with the Greek 'sphere,' but as early as the Sefer ha-bahir it is related to the Hebrew sappir ('sapphire'), for it is the radiance of God which is like that of the sapphire." 79

${ }^{79}$ Scholem, Kabbalah, 99-100. Although he does not cite the passage to which he refers, it would seem that he had in mind Sefer ha-bahir (ed. Daniel Abrams; Los Angeles: Cherub Press, 1994) $\S 65$. This passage does not directly refer to the sefirot, however, nor does it take up the question of 
Even if Scholem's etymology is correct, the astronomical association is not so easily avoided - as the spheres were understood to be made of the transparent crystalline substance known as sapphire. ${ }^{80}$ This sense is evident in a derivation suggested by Cordovero later in the Pardes: The sefirot are a power (כוח) that contains many opposites, "which is the reason they are called sefirot-from the term sapphire. For just as the sapphire has no distinguishing color but contains all the colors seen in it, so the sefirah contains all the opposites" (Pardes 8:2) ${ }^{81}$ This derivation was hardly Cordovero's innovation. The great Spanish kabbalist R. Abraham ben Eliezer ha-Levi (c.1460-c.1530), who wandered for over a decade following the expulsion before settling in Jerusalem, wrote regarding the nature of the sefirot and the derivation of their name: "Those sefirot that we have discussed are His attributes (מדותיו ית') by which the world operates and are fine, pure, crystalline (ספיריות) spiritual forms (צורות רוחניות). . . And in general all ten sefirot are fine and simple and crystalline, this being the reason they are called sefirot." "82 Such a derivation had also been suggested by the foundational Ma 'areket, in which "pavement of sapphire stone" (לבנת הספיר, Exodus 24:10) is given as a possible source of the

the derivation of the term, as does $\S 87$. See n. 82 below and cf. Scholem's remarks in Origins of the Kabbalah (Philadelphia: The Jewish Publication Society; Princeton: Princeton University Press, 1987) 26. The Scholem Archives at the National Library of Israel (ARC. 4* 159903 89) contain Scholem's notes on R. Joseph ben Shalom Ashkenazi's use of the term "orbs of the sefirot" (הלגליר (הספירות). Scholem commented that he was uncertain whether the term referred to an internal rotation (akin to that discussed below on volvelles) or simply to the sefirot themselves.

${ }^{80}$ See Y. Tzvi Langermann, "The True Perplexity: The Guide of the Perplexed, Part II, Chapter 24," in Perspectives on Maimonides: Philosophical and Historical Studies (ed. Joel L. Kraemer and Lawrence V. Berman; Oxford: Littman Library, 1991) 159-74, at 162-63 n. 16. The sefirot as "layers of an onion"-invoked just a few lines later by Cordovero-is also a topos with an astronomical pedigree. See Adena Tanenbaum, "Nine Spheres or Ten? A Medieval Gloss on Moses Ibn Ezra's be-Shem El Asher Amar," JJS 47 (1996) 294-310, at 300 n. 27. See also Giulio Busi, Mantova e la qabbalah (Milano: Skira, 2001) 40, 66.

${ }^{81}$ Cordovero continues in Pardes 8:2 to consider other etymological possibilities, basing himself, as kabbalists so often did, on the enigmatic opening of Sefer yeșirah, according to which God initiated creation by the engraving of the " 32 paths" in three books, each unhelpfully denominated with the same three unvocalized letters $S-P-R$. None of the alternatives, however, trumps his endorsement of sapphire. His second choice derives the term sefirah from sippur - story. Here too, however, the proof text is telling in its linking the kabbalistic term to the heavenly bodies: "because "the heavens tell (מספרים) the glory of God," (Ps 19:2) echoing the Bahir (Abrams ed. §87). Cordovero-and many other kabbalists - also uses the root in the adjectival form (ספיריי) to mean crystalline. See, e.g., Pardes Gate 10 (the Gate of Colors), ch. 2, where he writes (of the sefirah hokmah), "Some have regarded it as of crystalline color, which is a color that receives all colors; others have suggested that it is azure (tekelet), which is the ultimate (תכלית) of all colors."

${ }^{82}$ Cited in Gershom Scholem, "The Kabbalist R. Abraham ben Eliezer ha-Levi," Qiryat Sefer 2 (1924) 101-44, at 129-30 (Hebrew). Thanks to Levana Chajes for bringing this passage to my attention. Cf. the opening of a thirteenth-century commentary on the ten sefirot, perhaps composed by Moshe of Burgos, "And sefirah is derived from crystalline (וספירה לשון ספירית)." Cited in Catalogue of the Kabbalistic Manuscripts in the Library of the Jewish Community of Mantua (ed. Giulio Busi, Florence: Cadmo, 2003) 61 [MS ebraico 61, 60r]. 
term. ${ }^{83}$ Even the "Magnificent Parchment," to which I have already made mention more than once, prefaces its incomparable divinity map with the following text:

The intention of our sages of blessed memory was to speak of hidden things by means of the sefirot - whether the term refers to number (ספסר), to story (סיפור), or to the sapphire (ספיר) apprehended by the elders of Israel [referring to Exodus 24:10]. . . . Just as the sapphire that has no color but shines and receives all colors one after another, so are all things emanated from the Creator, may He be blessed. Therefore it is plausible to say that [the term] sefirot is derived from the term (מלשון) sapphire. ${ }^{84}$

Crystalline sapphire, crystalline spheres, crystalline sefirot: Scholem, ever inclined to oppose Kabbalah and philosophy, seems to have been uninterested in unpacking the conviction of the kabbalists that the sefirot and the spheres were analogous, if not continuous.

This indeed is Cordovero's point: The nested structure of the cosmos, from earth to infinity, is a function of the causal dependence of each onion-like orb on the one surrounding it. As he surveys this great chain, Cordovero weighs in on questions that were of great interest to medieval philosopher-scientists: how did Greek and biblical cosmological terms correspond, "heavens" (שמים) and "firmament" (רקיע) with the planetary spheres and the orb of fixed stars $?^{85}$ Cordovero argues that the seven firmaments in ancient Jewish sources are not to be identified with the planetary spheres, here designated by the commonly used Hebrew term for the celestial orbs (גלגלים). ${ }^{86}$ The firmaments are of an entirely different order. Moreover, the spheres

${ }^{83}$ Ma 'areket ha'elohut, 29. See also Hayyat's commentary ad loc.

${ }^{84}$ See above notes 9 and 66 . The quoted passage is in the top right corner of Oxford - Bodleian Library MS Hunt. Add. D (Neubauer 1949) and most other witnesses.

${ }^{85}$ In this spirit, Cordovero plunges here into a discussion of the ancient rabbinic sages' divergence from Greek scientific opinion on matters relating to the spheres, one that the Talmud records as having culminated in the rabbis deferral to their Greek contemporaries (see b. Pesah. 94b). For an example of these vexing questions in medieval Christian sources, see Thomas Aquinas, Summa theologiae (ed. and trans. William A. Wallace; Vol. X: Cosmogony; New York: McGraw-Hill; London: Eyre \& Spottiswoode, 1967) 71-87.

${ }^{86}$ Maimonides, in his authoritative Mishneh torah, identified the spheres of the Greek tradition (גלגלים) with various biblical terms. See Maimonides, Hilkot yesodey hattorah, ch. 3 (https://goo. $\mathrm{gl} / \mathrm{Jghxai}$ ). In one of the first extant kabbalistic works, the Sefer hayyihud (Book of Unity) by R. Asher ben David (mid-13 ${ }^{\text {th }}$ century), R. Asher also asserted that the difference between the Greek and Jewish cosmology was largely one of nomenclature, but now from a kabbalistic perspective. See Daniel Abrams, R. Asher Ben David: His Complete Works and Studies in His Kabbalistic Thought (Los Angeles: Cherub Press, 1996) 108 (Hebrew). The late-thirteenth-/early-fourteenth-century R. Menahem Recanati went so far as to assert that "our rabbis of blessed memory [usually referring to talmudic-era sages] said that sefirot were called galgalim." Sefer ța 'amey hammișvot haššalem, (London, 1963) 79b. And see Ma 'areket ha'elohut, 233, 275-76. Mention should also be made of the fascinating terminology "גלגלי הספירות" used by the fourteenth-century kabbalists R. David ben Judah he-Hasid and R. Joseph ben Shalom Ashkenazi, discussed in Kabbalistic Commentary of Rabbi Yoseph Ben Shalom Ashkenazi on Genesis Rabbah (ed. Moshe Hallamish; Jerusalem: Magnes Press, 1985) 24-27 (Hebrew); Idel, "Visualization of Colors, I," 50. Cordovero uses the term גלגל הספירות in 'Or yaqar, (Vol. 5: Jerusalem, 1970) 44b. 
(whatever their precise number, which was also contested) were all located within one firmament, the lowest of the seven. This discussion allows Cordovero to set forth a fully articulated statement of a chain of being extending from the Infinite (אין סוף), through the sefirot, the firmaments, and the spheres, to the very core of the earth. Cordovero approvingly cites a zoharic passage according to which "the firmaments encompass the world and the spheres (גלגלים) and everything . . . and so too in this manner is the matter of the sefirot, for they are all within the Infinite (אין סing of Kings, and within Keter is Hokmah, and within Hokmah is Binah" (36a). All ten sefirot are named, nested one in another, to the tenth, Malkut. If the discussion so far has implied an analogous relationship between astronomical and sefirot structure, at this point Cordovero continues:

Within Malkut is [the World of] Beriyah (Creation, the second of the four worlds), within Beriyah Yeșirah (Formation, the third of the four worlds), within Yesirah 'Asiyah (Action, the last of the four worlds). And within them are included Ma'aseh Berešit (Work of Creation, i.e., cosmogony) and Ma'aseh Merkabah (Work of the Chariot, i.e., cosmology). ... And within Ma'aseh Berešit are the spheres (גלגלים), and within the spheres the earth, and within the earth, at its navel, the seven earths.

After adducing a long zoharic passage, Cordovero concludes,

It is therefore demonstrated by this passage that in the navel of the earth there are seven earths, one within another, in the manner of the spheres, and in this way we ascend from the point of the earth to the first cause, the 'Eyn Sof, and all that is within it. With this, we will be able to understand that which they said, "He is the place of the world and the world is not His place." 87

It is not only that the chain of being is continuous and uninterrupted, but that the entire chain shares a common structural principle, or "seal" as Cordovero calls it elsewhere. ${ }^{88}$ And lest he be accused of corporealizing the divine, he reminds his reader of the rabbinic dictum that God is the place of the world-which is to say that God created space itself. ${ }^{89}$ Moreover, he writes, scientists agree that beyond the ninth sphere there is no space, the tenth Intellective Sphere being the placeless ground of space.

At this point, Cordovero introduces the last sefirotic diagram of the sixth gate, a venerable one found already in the 1284 Parma manuscript [Figure 10]. This diagram represents the structure of the sefirot in the form of an astronomical rota, though with a twist: each is figured by the first letter of its name, with the outmost

${ }^{87}$ Cf. Cordovero, Pardes rimmonim, 15b-16a (which includes a concentric circle diagram), discussed in Yoseph Ben Shlomo, "R. Moshe Cordovero's Attitude Towards Philosophy and the Sciences," Sefunot 6 (1962) 193-258, at 247 (Hebrew).

${ }^{88}$ See Ben Shlomo, The Doctrine of God of R. Moses Cordovero, 286-88; Bracha Sack, "Moshe Cordovero and Isaac Luria," Jerusalem Studies in Jewish Thought 10 (1992) 311-40, at 334-35.

${ }^{89}$ Cf. Brian P. Copenhaver, "Jewish Theologies of Space in the Scientific Revolution: Henry More, Joseph Raphson, Isaac Newton and Their Predecessors," Annals of Science 37 (1980) 489-548. 


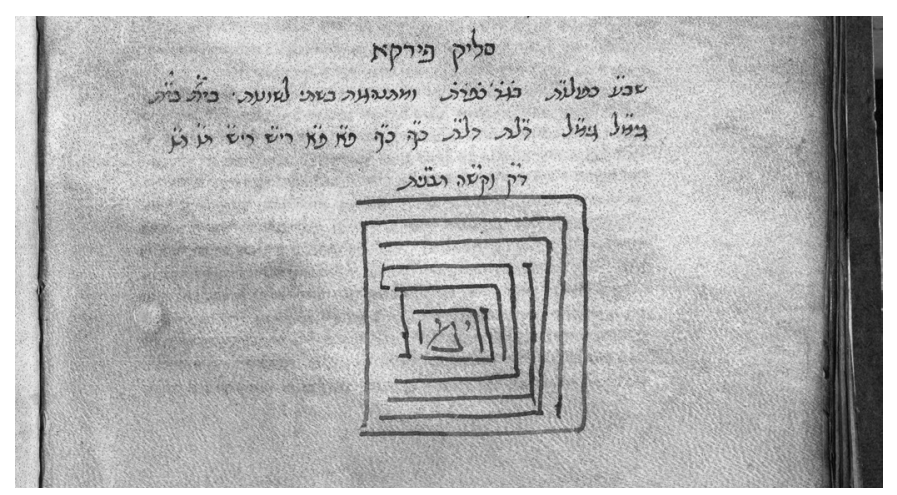

Figure 10: Biblioteca Palatina, Cod. Parma MS 2784, 43v under concession by the Ministry for Cultural Heritage and Activities.

circle of Keter implied by the letter kaf, and so on, to the innermost mem of Malkut. This diagram would be reproduced in myriad contexts over the course of nearly nine centuries, with only minor variations such as the substitution of the centered mem with an 'ayin for 'Atarah, one of the appellations of the same sefirah. The nesting structure is described here as resembling the layers of an onion, a simile with a long astronomical pedigree..$^{90}$ Not long after Cordovero, R. Hayyim Vital would make the astronomical association explicit in his own discussions of the sefirot, writing that they were nested within one another "as the skins of onions, one within another, in the manner of the image of the spheres (תמונת הגלגלים) of astronomical books (בספרי תוכניים). Acre, who had used it in his Me'irat 'eynayim to articulate the concept of cosmic continuity, from the first emanated sefirah to the lowest rung of earthly creation. ${ }^{92}$ The kaf of the first and outermost sefirah of Keter is "home to them all," recalling the Hebrew letter bet with which the Torah begins, and which the ancient rabbinic sages regarded as a homograph for home (בית) to creation. Despite his valiant efforts to offer a de-spatialized reading of this diagram, Cordovero was unable to avoid the structural analogy, and reminds his reader that "we have learned that the matter of emanation (אצילות) resembles the spheres surrounding this world, one within another like onion layers, called firmaments, and that their operation (הנהגתם) resembles the operation of the lower firmaments. They are spheres encompassing (והם גלגלים מקיפים) everything within them."

Cordovero's seventh gate shifts the focus from the sefirotic hubs and their array to the channels that connect them. Visualization is still central to the presentation, but this time without the need to survey a range of opinions regarding configuration.

\footnotetext{
${ }^{90}$ See note 80 above. The simile was used by Maimonides in Hilkot yesodey hattorah 3, 2. See Shlomo Sela, "Maimonides and Māshā'allāh on the Ninth Orb of the Signs and Astrology," Aleph 12 (2012) 101-34, at 105-106.

${ }_{91}$ 'Es hayyim Gate I, Branch 2. The expression recurs with some frequency in Vital's work.

${ }^{92}$ Me'irat 'eynayim (Goldreich, 1981) 118; (Jerusalem, 1975 ed.) 153.

${ }^{93}$ Cordovero, Pardes rimmonim, 37b.
} 


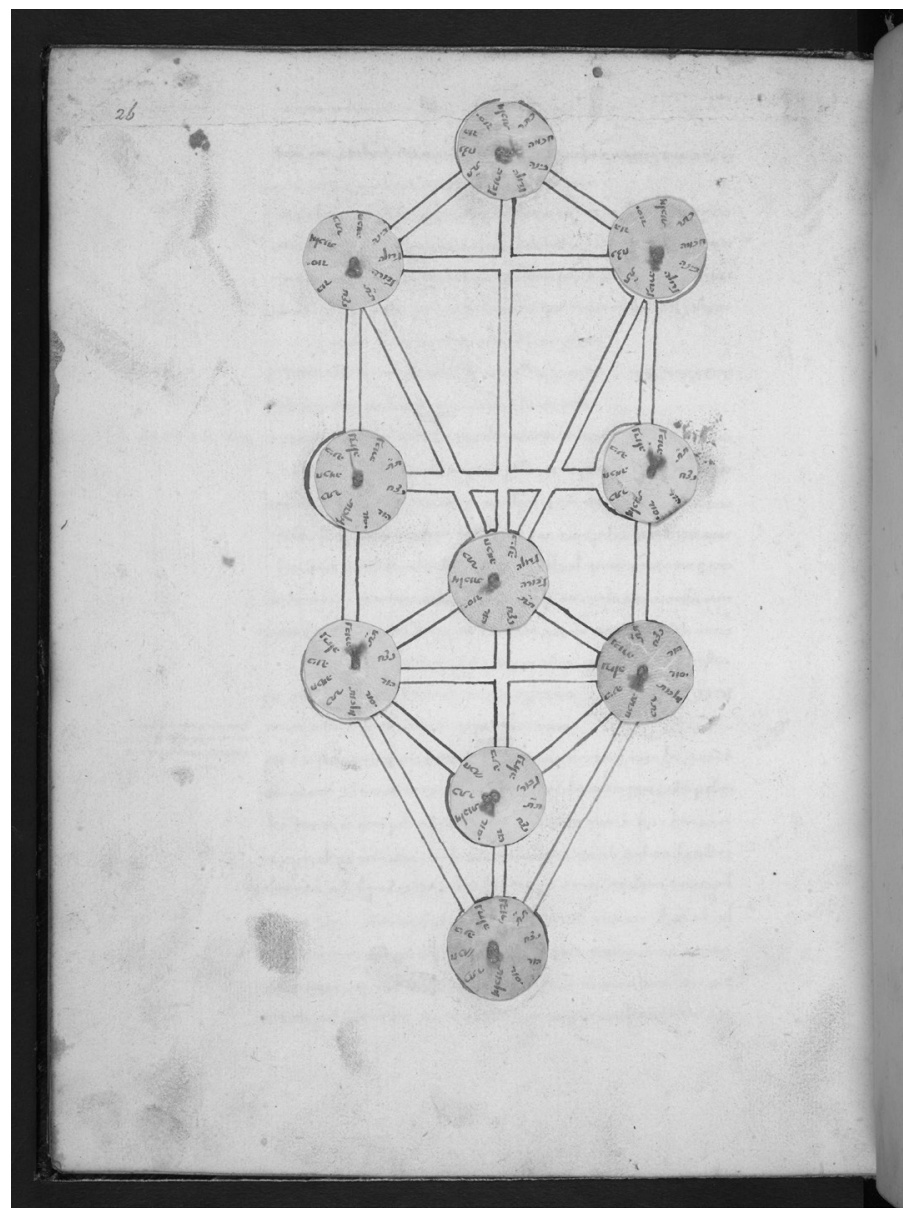

Figure 11: (C) British Library Board (British Library Add. MS 27091 26r); Polonsky Foundation Catalogue of Digitised Hebrew Manuscripts.

The theoretical question is now one of process: how do these hubs "communicate" with each other? The theoretical answer rests upon the principle of sympathies, namely that similarity establishes connectivity. ${ }^{94}$ Were the sefirot simple, distinct essences, they would be unable to establish the network through which pulses the divine flux, or $\breve{s} e f a$; , en route to its diverse manifestations. Invoking an axiom of early Kabbalah, Cordovero explains that each sefirah contains them all. When similar aspects of different sefirot are aligned, a channel between them becomes operative. ${ }^{95}$ But knowing the theory isn't enough: "There are so many variations

${ }^{94}$ For the classic treatment of this principle, see the second chapter of Michel Foucault, The Order of Things: An Archaeology of the Human Sciences (New York: Tavistock Publications, 1970). See also Stuart Clark, Thinking With Demons: The Idea of Witchcraft in Early Modern Europe (Oxford: Clarendon Press, 1997), esp. 214-32.

${ }_{95}$ These inner aspects are not limited to ten within ten, but continue ad infinitum, with 10 within 
(חלוקות) that it is impossible for one to grasp them (לעמוד בהם) without the material drawing (ציור הגשמי) that we will draw before you: ten circles, and in each and every circle, ten facets (פנים) that are ten aspects (בחינות), the ten sefirot in each of the ten sefirot. And the facet [of one] will revolve opposite the facet [of another]."

Cordovero's language is worth noting here, using "material drawing" to emphasize that this visualization is not (merely) in the mind's eye, but a drawn diagram - and one with moving parts [Figure 11]. In such a diagram, each sefirotic hub anchors a revolving disc upon which, like the numbers on a clock, the names of all ten sefirot are inscribed. Beside these lines, in the margins of MS Vat. Neof. 28 $(27 \mathrm{v})$, Athanasius Kircher wrote "10 Rotae," clarifying the meaning of a Hebrew text that lacked a technical term for the mounted rotating instruments known as volvelles. ${ }^{97}$

Volvelles, essentially two-dimensional adaptations of the astrolabe, had been in use as calculation devices with a range of applications, from calendrical to mystical, going back in the West to Matthew Paris and Ramon Llull, the latter using them in his late thirteenth-century Ars Magna.$^{98}$ In the Hebrew manuscripts of Cordovero's time, they were most commonly found in copies of Sefer yeșirah, where they usefully suited the work's combinatory exercises. Here, Cordovero deployed them to bridge theory and practice. Cordovero gives a few examples of complex disc rotations that produce distinct results, but concludes with the simplest: "Now, if we rotate Hokmah alone ten times to each of the ten facets of Keter-without changing or rotating the facets of the rest of the sefirot - the number of types of flux will reach 100." Writing out all possible sequences is clearly out of the question, as even the simplest operations produce overwhelming results: they are literally "impossible to put in writing." That being the case,

If a person wants to accustom himself to them [the varieties of flux], he should engage himself with the form drawn (בצורה המצוירת) before him and contemplate it for many days, until God enlightens the eyes of his intellect. For the power of the pen fails to elaborate upon these things further, if one does not receive the matter "from mouth to mouth," or as an enlightened one probing them with his intellect by means of this form. And this form is

the 10 that are in each of the 10 sefirot, and so on. By this first level down the possibilities reach $100^{10}$ (100 billion billion).

${ }^{96}$ The passages quoted here are translated from Vat. Neof. 28, 27v, which corresponds to Cordovero, Pardes rimmonim 43b. Divergences will be noted below.

${ }^{97}$ On volvelles, see Suzanne Karr, "Constructions Both Sacred and Profane: Serpents, Angels, and Pointing Fingers in Renaissance Books With Moving Parts," The Yale University Library Gazette 78 (2004) 101-27. By the time Kircher consulted this manuscript, some hundred years had passed since its preparation. We do not know when this supplemental diagram was lost, but Kircher's comment may also reflect a clarification necessary in its absence. See also above, note 53 , and below.

${ }^{98}$ See, e.g., http://gallica.bnf.fr/ark:/12148/btv1b90684818/f48.item. On the volvelles of Matthew Paris, see Daniel K. Connolly, The Maps of Matthew Paris: Medieval Journeys Through Space, Time and Liturgy (Woodbridge: Suffolk Boydell Press, 2009) 64-67. My thanks to Marcia Kupfer for bringing this discussion to my attention. 
written upon the page that is before you (בדף שלפניך) on the parchment page (בדף הקלף).

Cordovero, a prolific writer throughout his life, was hardly one to discount the power of the written word, but here admits that, for certain types of understanding, words fail. ${ }^{100}$ Nevertheless, when faced with the impossibility of verbally communicating to his readers the true generative nature of the sefirotic tree, Cordovero fashioned an operational instrument built for simultaneous digital (lit. finger) manipulation and contemplation. Moreover, this technology is promoted as an effective replacement for the only possible, albeit unlikely, alternative: initiation into the oral tradition by a master, "mouth to mouth." This phrase evokes the introduction of Nachmanides to his biblical commentary, in which he declared that the secrets of the Torah were passed down exclusively "from mouth to mouth." ${ }^{101}$ For Nachmanides, there was no alternative; for Cordovero, the diagram offered a performative exercise that produced the same results as authoritative initiation. And although it was true that Cordovero feared that the encounter with material drawings of the sefirotic tree might lead to a corporeal conceptualization of the divine, he would ultimately validate it as typically Jewish. Like so much of Jewish tradition, he concluded, the material - in this case, a drawn diagram — served to facilitate the manipulation and circulation of divine energy. Whether an 'ilan or a lulab (the palm frond shaken during the Sukkot festival), each, as he phrased it, functioned as "a body to clothe spiritual reality" (גוף להתלבש המציאות הרוחני).

\section{Circles and Trees: Kabbalah, Astronomy, and Natural Philosophy}

The discursive analysis of Cordovero's masterly treatment of the sefirotic array has shown how profoundly their conceptualization and visualization were indebted to the astronomical tradition. The kabbalistic use of schemata with astronomical

${ }^{99}$ Vatican Neof. 28, 27v. The first printed edition omits "on the parchment page." The printer subsequently added a gloss explaining to the reader that Cordovero's intention will become clear if the sefirot drawn on the verso are imagined as spinning discs - as they were in the manuscript upon which the printed edition was based. See Cordovero, Pardes rimmonim, 43b. The Vatican MS no longer contains the parchment page diagram to which Cordovero referred that sported the volvelles. The diagram page was evidently a special insert and, unlike the rest of the codex, on parchment rather than paper. On this manuscript, see Hebrew Manuscripts in the Vatican Library: Catalogue (ed. Benjamin Richler; Città del Vaticano: Biblioteca Apostolica Vaticana, 2008) 549. Other early Pardes witnesses, including the sixteenth-century Jerusalem - National Library of Israel Ms. Heb. $4^{\circ} 626$, have reached us with the volvelle diagram intact, and numerous manuscripts of the early abridgment of the Pardes by Cordovero's student Samuel Gallico retain this diagram with working volvelles. See, for example, the 1588 copy at the British Library - Add MS 27091.

${ }^{100} \mathrm{I}$ explore this theme in J. H. Chajes, "Kabbalistic Diagram as Epistemic Image," Pe 'amim 150 (2017) 235-88.

${ }^{101}$ See now Yair Lorberbaum, "Did Nahmanides Perceive the Kabbala as 'Closed Knowledge'?," Zion 82 (2017) 309-54 (Hebrew).

${ }^{102}$ Moses Cordovero, 'Or Yaqar (Vol. 21: Ši ‘ur qomah I; Jerusalem, 1991) 190a. See also Uri Safrai, " "Service of the Heart' in Sixteenth-Century Kabbalah" (PhD. diss., Ben-Gurion University of the Negev, 2016) 241 n. 26 (Hebrew). 


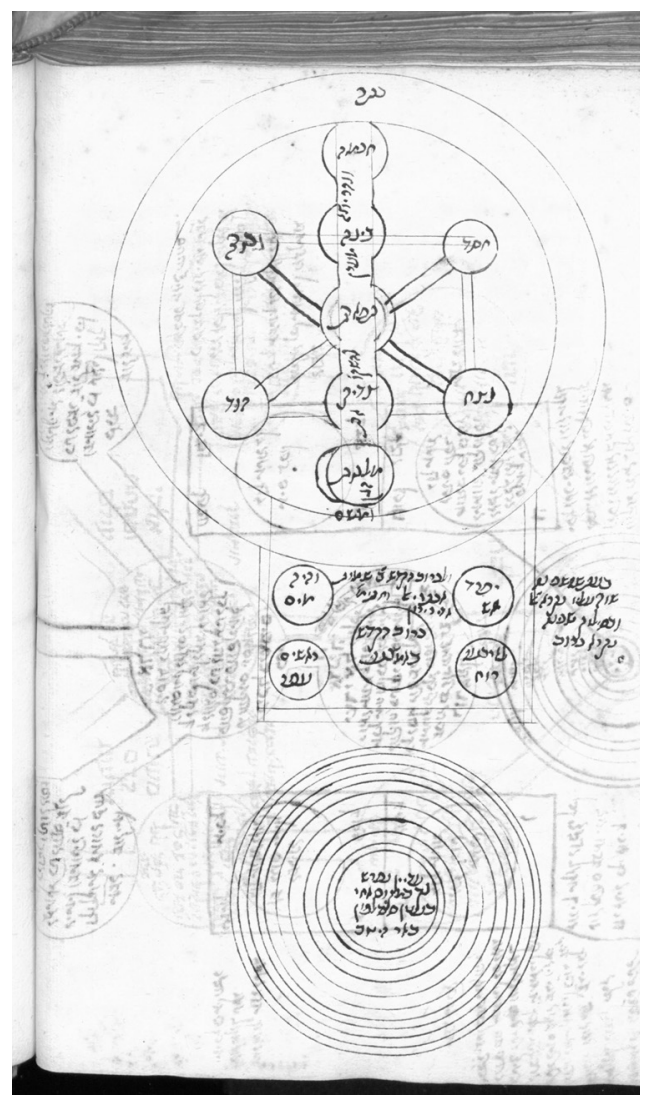

Figure 12: Obras Cabalísticas, 'Eser Sefirot Belimah [Escuela de Estudios Árabes (CSIC) Ms64, fol. 282v]. http://simurg.bibliotecas.csic.es/viewer/image/ CSIC001353367/576/ pedigrees went hand in hand with the assertion of cosmological ontological continuity, the adoption of common metaphors, and, of course, the borrowing of technical terms (constellations, houses, etc.). If the onion skins of ancient astronomy now describe the structure of the sefirot, the circle-sphere schema is a natural choice for their diagrammatic representation.

Yet this analysis raises the question of why the tree, a schema with no astronomical application, was so widely embraced as a visual representation of these same sefirot. ${ }^{103}$ Gerhart Ladner's remarks are salient in this context: "The vegetative-organic tree schemata of the Middle Ages - and even the considerably modified tree symbolism of the Renaissance-were apt to express and represent something of the graded and continuous, and nevertheless differentiated, structure of the Christian cosmos of those ages." 104 Jews in particular would have been receptive to an arboreal visualization of the sefirot given the prominence of Tree of Life mythologomena in Jewish culture from the Bible to the Bahir. ${ }^{105}$ Without discounting these factors, I should nevertheless like to offer an additional hypothesis — one foreshadowed throughout this essay.

103 The conflation of the arboreal and circular schemata by kabbalists has also been noted, for example, in R. Joseph ben Shalom Ashkenazi's commentary on Sefer yeșirah (published under the name "Raabad" in the standard edition, 18b) where he describes the concentric-circle diagrams of the sefirot as "circle trees (!) (אילנות עגולים), as their sefirot are circle-spheres (עיגולים כדורים)." See Idel, "Visualization of Colors, I," 51.

${ }^{104}$ Gerhart B. Ladner, "Medieval and Modern Understanding of Symbolism: A Comparison," Speculum 54 (1979) 223-56, at 254. See also Cynthia Robinson, "Trees of Love, Trees of Knowledge: Toward the Definition of a Cross-Confessional Current in Late Medieval Iberian Spirituality," Medieval Encounters 12 (2006) 388-435; The Tree: Symbol, Allegory, and Mnemonic Device in Medieval Art and Thought (ed. Pippa Salonius and Andrea Worm; Turnhout: Brepols, 2014).

${ }^{105}$ In the earliest extant commentary on Sefer yeșirah composed by R. Saadiah Gaon, Saadiah 


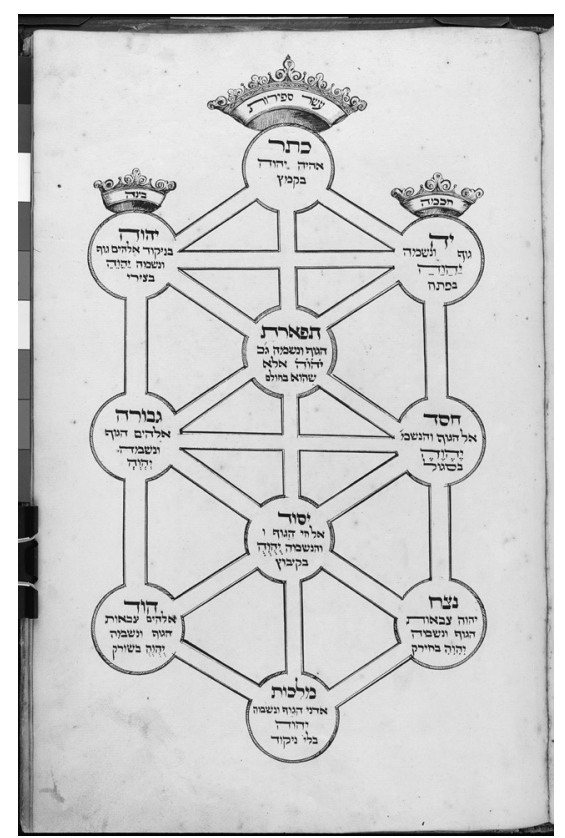

Figure 13: Prague Jewish Museum MS 69 (170.219), 182r. Reproduced with permission from the Jewish Museum in Prague Photo Archive.
The two fundamental disciplines devoted to developing models of the universe going back to the Greeks were astronomy and natural philosophy. The former attended to the heavens, and the latter to the sub-lunar physical or elemental realm. The perfect spherical universe conceived and visualized by the originally mathematical astronomers enjoyed a long cosmographical afterlife, including its appropriation by kabbalists. Although one finds fewer diagrams in works of natural philosophy than in astronomical treatises, the former routinely deploy squares of opposition and arboreal diagrams to express the dialectical transformations of the four elements and four qualities (hot and cold, dry and humid). If the spherical structure of the universe was consistent from heavenly orbs to divine sefirot, its perfection was, by definition, changeless. Diagramming the sefirot as concentric circles asserts their cosmogonic priority and primordial perfection. The kabbalists, though, needed more from their visualization than changeless perfection could offer. Having developed a notion of the sefirot as the elemental categories from which all of creation was constituted, kabbalists occupied themselves with contemplating their dialectical interactions and combinations. These were what accounted for the variety of creation. Enter the kabbalistic tree: it may resemble a Porphyrian Tree, but rather than drilling down from the general to the particular, its categories are hypostases, ontologized elements arrayed in generative "triadicity." Its nablas and deltas synthesize oppositions and differentiate unities. The tree schema offers a conceptual richness unattainable by astronomical circles, allowing for the sefirot to interrelate dynamically and endlessly. A portion of the kabbalistic tree might also be isolated to form a "square of opposition," another standard, even ubiquitous schema of medieval natural philosophy [Figure 12]. ${ }^{106}$

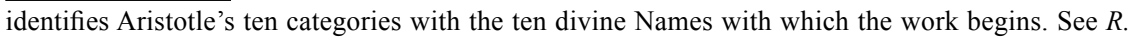
Sa'adiah Gaon's Commentary to Sefer Yeșirah (ed. Yosef Kapah; Jerusalem, 1972) 46; Sendor, "The Emergence of Provencal Kabbalah," 61-62. See also Busi, Qabbalah Visiva, 78.

${ }^{106}$ See also Cordovero, Pardes, Gate 8, chapter 11, for a sefirotic square of opposition. My reflections on the triadicity of tree diagrams are indebted to ongoing correspondence with Dr. Martin Zwick, a professor of biophysics whose expertise is in systems theory and methodology. 
Another advantage of the arboreal schema was in its branches - the subject of the discussion in the Pardes that follows Cordovero's treatment of sefirotic arrays. These branches were correlated to the twenty-two letters of Sefer yeșirah $(3+7+12)$, and ontologized as the channels through which the divine effluence flowed. A typical three-columned Tree of Porphyry with its ten "nodes" in the 3-4-3 array fits the $3+7+12$ of Sefer yeșirah perfectly. There are three possible horizontal lines, precisely seven lines that "double" within a given trajectory, and twelve diagonal lines connecting the rest [Figure 13]. ${ }^{107}$ Despite this neat fit, the consensus that the bottom node representing Malkut/Škekinah had to be lower than the rest of the structure made it necessary to establish rather less elegant correspondences. The symmetrical array is rarely found in kabbalistic manuscripts.

I have endeavored to provide something of an introduction to classical kabbalistic sefirotic diagrams that nevertheless advances a particular thesis. This has meant forgoing a more thorough inventory of kabbalistic iconography, as well as a sustained treatment of important questions ranging from their Sitz im Leben and diverse uses, from meditation to memory to magic, as well as a consideration of the very salient question of the effect of their media, or the 'ilanot as material texts. ${ }^{108}$ Classical kabbalists, to be sure, were hardly earnest students of astronomy and natural philosophy, but they did understand their own project in scientific terms. They saw no discontinuity on the spectrum of scientific pursuits. On the contrary, Kabbalah was for them the science of the divine, crowning rather than opposing the enterprise. It was only natural that in conceptualizing and communicating this divine science, kabbalists appropriated the visual and rhetorical languages of astronomy and natural philosophy, the most prestigious scientific disciplines of their day. Astronomy and natural philosophy were not what the kabbalists talked about, but how they talked about it. For kabbalists, if not for philologists, the sefirot-spheres connection was always crystalline-clear.

${ }^{107}$ My thanks to Josh Lauffer for sharing this insight with me.

${ }^{108}$ Many of these issues are taken up in publications cited above. See also the recent discussion in J. H. Chajes, "Kabbalah Practices/Practical Kabbalah: The Magic of Kabbalistic Trees," Aries 19 (2019) 112-45. 